\title{
Flora da Serra da Arara: Rubiaceae Juss.
}

\author{
Aclébia Alves Quaresma ${ }^{1,2}$ (i) \& Maria do Socorro Pereira ${ }^{1}$
}

(1) Universidade Federal de Campina Grande, Centro de Formação de Professores, Unidade Acadêmica de Ciências Exatas e da Natureza, Rua Sérgio Moreira de Figueiredo, Casas Populares 58900-000, Cajazeiras, Paraíba, Brasil. E-mail: mspereira@ufcg.edu.br

(2) Universidade Federal de Pernambuco, Centro de Ciências Biológicas, Departamento de Botânica, Programa de Pós-Graduação em Biologia Vegetal, Avenida Professor Moraes Rego 1235, Cidade Universitária 50670-901, Recife, Pernambuco, Brasil. E-mail: aclebialves@gmail.com

Quaresma A.A. \& Pereira M.S. (2020) Flora da Serra da Arara: Rubiaceae Juss. Pesquisa e Ensino em Ciências Exatas e da Natureza, 4: e1298. http://dx.doi.org/10.29215/pecen.v4i0.1298

Editora acadêmica: Marla Ibrahim Uehbe de Oliveira. Recebido: 15 Março 2019. Aceito: 02 Dezembro 2019. Publicado: 14 Janeiro 2020.

Resumo: A Serra da Arara, localizada na região de Cajazeiras, abriga uma diversidade biológica nunca antes investigada, entretanto, ações antrópicas intensas vêm ameaçando as formas de vida neste ambiente. Assim, este trabalho objetiva realizar o estudo das Rubiaceae ocorrentes na área, contribuindo para o conhecimento da flora regional. O material foi processado seguindo-se as técnicas usuais de herborização e depositado no herbário JPB, sendo as análises dos caracteres morfológicos feitas no Laboratório de Botânica, da Universidade Federal de Campina Grande. A partir de coletas aleatórias produziram-se descrições, uma chave analítica para identificação das espécies, registros fotográficos, indicação da distribuição geográfica e comentários dos táxons. Rubiaceae está representada na Serra da Arara por 10 espécies e sete gêneros, onde Borreria G. Mey., é o mais representativo com três espécies, Tocoyena Aubl. com duas e os demais, Hexasepalum Bartl. ex DC., Oldenlandia L., Richardia L., Spermacoce L. e Staelia Cham., com apenas uma espécie cada. Destaca-se ainda, um novo registro para a Paraíba (Oldenlandia corymbosa L.). Portanto, os presentes dados poderão embasar futuros estudos taxonômicos que auxiliem no desenvolvimento de iniciativas que busquem a preservação, conservação e manutenção da biodiversidade na região.

Palavras chave: Diversidade, Taxonomia, Sertão Paraibano.

\section{Flora da Serra da Arara: Rubiaceae Juss.}

Abstract: The Serra da Arara, located in the region of Cajazeiras, comprises a biological diversity never investigated before, however, intense anthropic actions are threatening the life forms in this environment. Thus, this article aims to conduct the study of Rubiaceae occurring in the area, contributing to the knowledge of the regional flora. The material was processed following the usual herbarium techniques and deposited in JPB Herbarium and the morphological characteristics analysis was made at the Federal University of Campina Grande's Botany Laboratory. Descriptions, an analytical key for species identification, photographic records, geographic distribution data and commentary of taxa were produced from random collections.Rubiaceae is represented in Serra da Arara by 10 species and seven genera, where Borreria G. Mey. is the most representative with three species, Tocoyena Aubl., with two species and the others, Hexasepalum Bartl. ex DC, Oldenlandia L., Richardia L., Spermacoce L. and Staelia Cham., with only one species each. Also noteworthy is a new record for Paraíba (Oldenlandia corymbosa L.). Therefore, the present data support future taxonomic studies to assist in the development of initiatives that seek the preservation, conservation and maintenance of biodiversity in the region.

Key words: Diversity, Taxonomy, “Sertão Paraibano”.

\section{Introdução}

Rubiaceae Juss. contempla uma grande diversidade dentre as Angiospermas, ocupando a quarta posição em número de espécies, ficando atrás apenas das Orchidaceae, Asteraceae e 
Leguminosae (Fabaceae sensu latu) (Delprete \& Cortés-B 2006; Delprete \& Jardim 2012). Seu nome vem do latim rubium referindo-se à tinta vermelha produzida nas raízes de algumas espécies (Cronquist 1981).

É composta por cerca de 614 gêneros e 13.300 espécies, sendo Psychotria L. o maior, com 2.000 representantes (Bremer \& Erikson 2009; Zappi 2009; Stevens 2019). Tem distribuição cosmopolita com predominância nas regiões tropicais e subtropicais, alguns táxons ocorrendo nas temperadas, entretanto, ausentes no Ártico (Mendonza et al. 2004). No Brasil está presente em todos os biomas e ecossistemas, sendo uma das mais representativas em levantamentos florísticos e fitossociológicos, com cerca de 125 gêneros e 1.405 espécies; deste total, 411 espécies e 83 gêneros estão distribuídas na Região Nordeste, 40 gêneros e 85 espécies com ocorrência no estado da Paraíba (Mendonça et al. 2013; Flora do Brasil 2020 - em construção).

A riqueza dessas plantas pode estar relacionada às suas diversas formas de vida, variando desde ervas até árvores de grande porte (Bremer \& Eriksson 2009). Além disso, variações dos tipos de flores, adaptados a uma gama de polinizadores, frutos diversificados, mecanismos de dispersão e acumulação de diferentes substâncias químicas atrativas podem contribuir para essa diversificação (Bremer \& Eriksson 2009).

Os caracteres diagnósticos do grupo são folhas simples, opostas ou verticiladas, estípulas interpeciolares, inteiras ou fimbriadas, muitas vezes com coléteres, flores gamopétalas 4-5-(6) meras, estames isostêmones, alternos aos lóbulos da corola, epipétalos e ovário ínfero (Bremer 1996; Pessoa \& Barbosa 2012; Souza et al. 2014).

Devido à plasticidade fenotípica dos caracteres morfológicos que Rubiaceae apresenta, foram necessárias divisões infra familiar para o estudo taxonômico detalhado da mesma (Robbrecht 1988). Tais classificações divergiram entre os autores que as propuseram, até estabelecer a mais recente separando-a em três subfamílias: Cinchonoideae, Ixoroideae e Rubioideae (Bremer \& Eriksson 2009).

Os primeiros estudos com a família no Brasil foram os de Vellozo (1827), Gardner (1838), Müller Argoviensis (1875, 1881), Schumann (1888, 1889) e Martius (1888, 1889) tornando-se mais frequentes a partir do século XX. Dentre as investigações envolvendo o grupo no estado da Paraíba, poucos são os tratamentos taxonômicos realizados, podendo destacar os trabalhos de Pereira \& Barbosa (2004, 2006), Melo \& Barbosa (2007), Pessoa \& Barbosa (2012) e Pereira \& Pereira (2018).

A região imediata de Cajazeiras (IBGE 2017), inserida no domínio da Caatinga, apresenta uma vegetação heterogênea adaptada a longos períodos de baixa disponibilidade hídrica e curtas quadras chuvosas, estas ocorrendo de janeiro a abril (Menezes et al. 2008). É neste contexto que se encontra a Serra da Arara, região serrana onde não há, até o momento, nenhum estudo com abordagem dos seus caracteres físicos, biológicos, químicos e/ou geológicos.

Em função da escassez de estudos da flora no sertão paraibano e a ausência de pesquisas para a área investigada, o referido trabalho objetivou registrar a diversidade de Rubiaceae na Serra da Arara, suprindo assim uma lacuna de estudos florísticos na Paraíba, em área de Caatinga, e embasando o desenvolvimento de futuros projetos de cunho taxonômico e/ou demais trabalhos que visem à conservação e manutenção da biota na região.

\section{Material e Métodos}

\section{Área de estudo}

A Serra da Arara, inserida na região imediata de Cajazeiras, abrangendo os municípios de São João do Rio do Peixe, Santa Helena e Cajazeiras, apresenta extensão de $4.59 \mathrm{~km}$ e elevação média de $428 \mathrm{~m}$ (Figura 1). A vegetação é xerófila com uma fitofisionomia da Caatinga arbustiva-arbórea. $\mathrm{O}$ solo apresenta-se pedregoso a argiloso, de coloração cinza a avermelhada (Figura 2A-E), recursos hídricos são representados por riachos, lagoas intermitentes e reservatórios, como açudes, os quais são alimentados por fontes que se formam no topo (Figura 2F-G). Os riachos seguem um percurso relativamente extenso sendo constituídos de numerosas 
rochas que dificultam o acesso à área de estudo (Figura 2F). Estes afloramentos rochosos são frequentes nas partes mais altas, e servem de abrigo para a fauna local, favorecendo ainda ao estabelecimento de outros grupos de plantas como briófitas e pteridófitas (Figura 3A-B).

Práticas agrícolas são comuns na Serra da Arara, e variam desde desmatamento para plantações e produção de carvão até a retirada de areia para construção civil, aterramentos e recuperação de estradas de terra firme (Figura 3C-D).

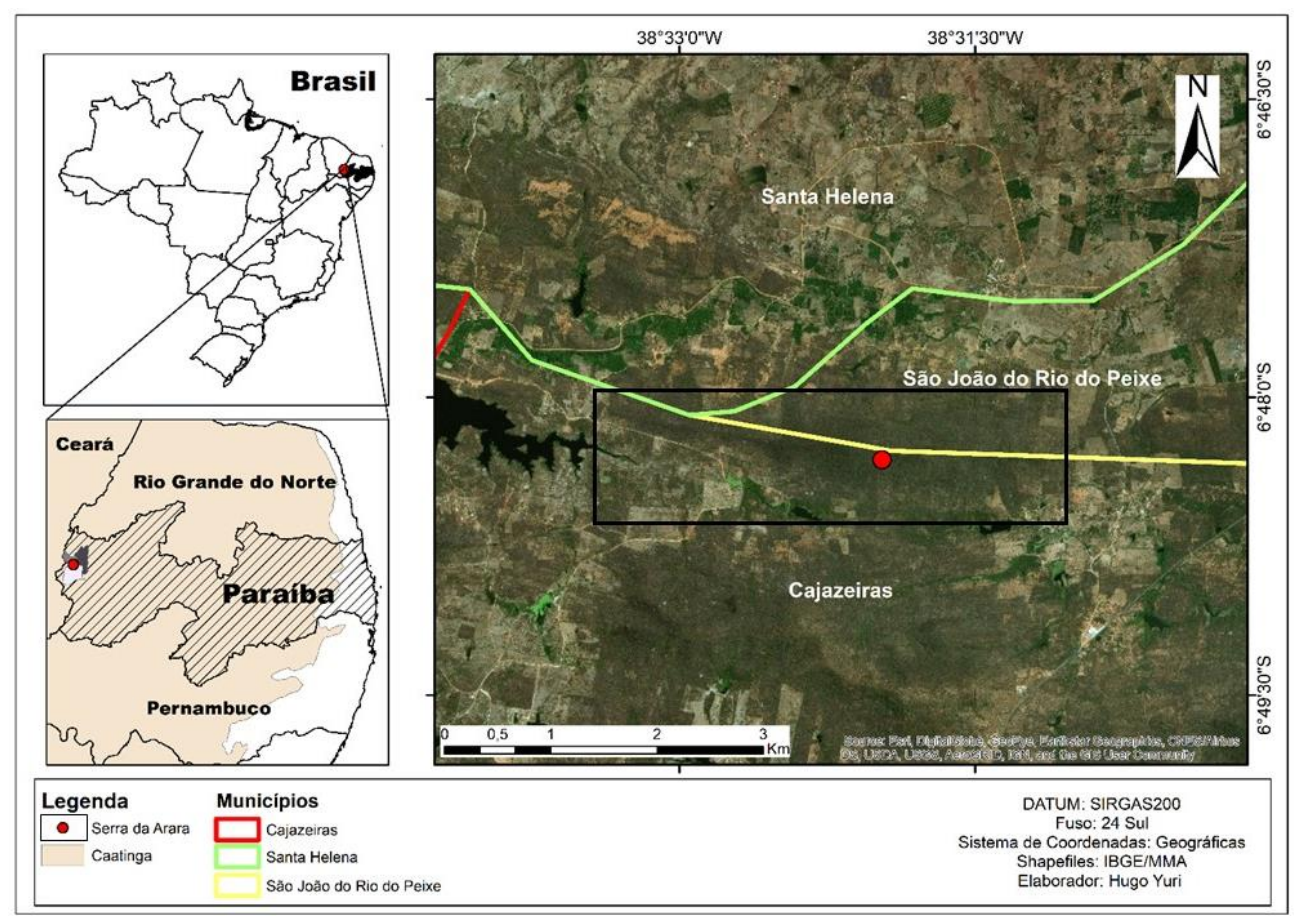

Figura 1. Localização da Serra da Arara.

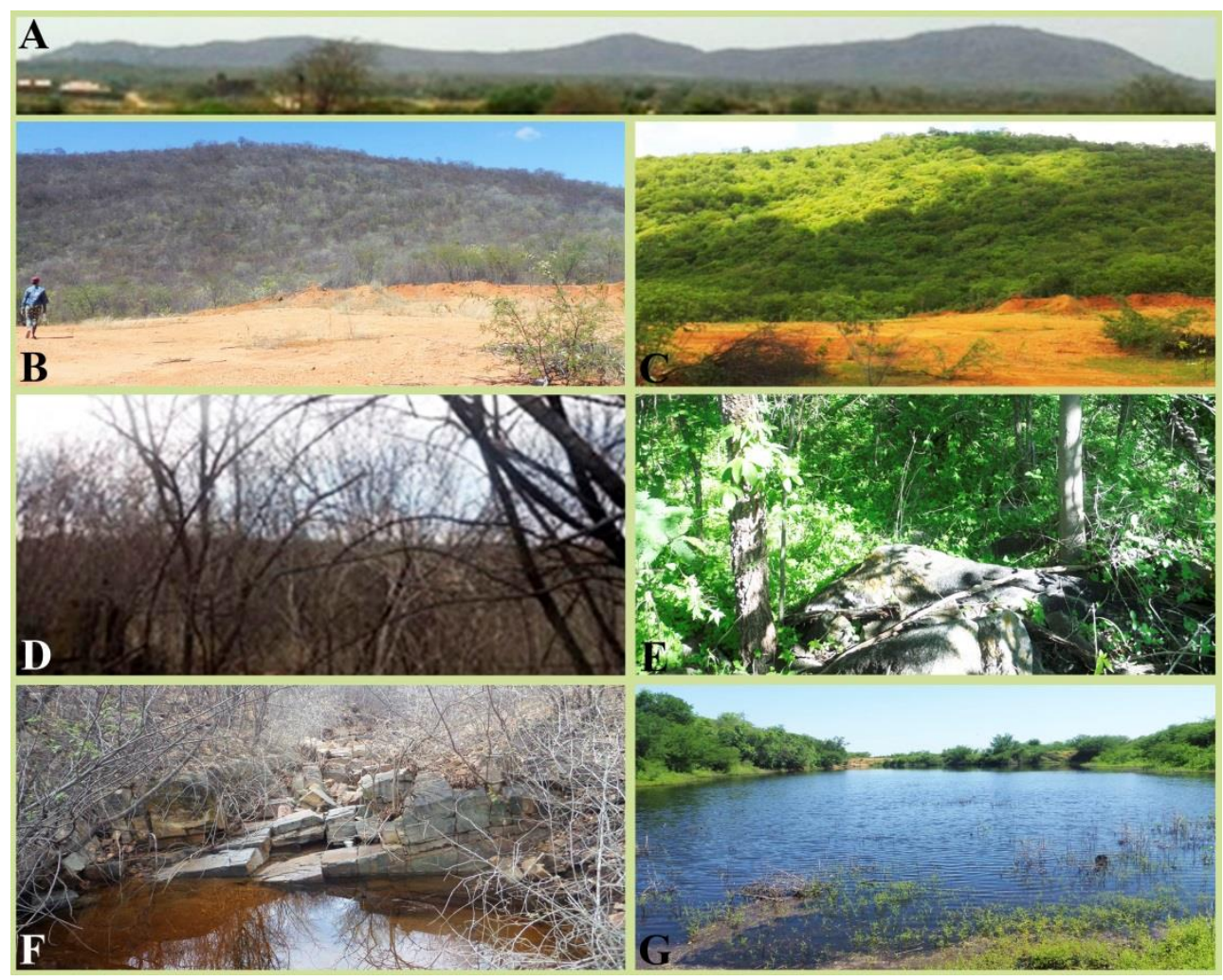

Figura 2. Vegetação e solo da Serra da Arara: A. Vista panorâmica da Serra da Arara; B. Solo argiloso (período seco); C. Um dos pontos mais elevados no período chuvoso; D. Vegetação caducifólia no período seco; E. Vegetação no período chuvoso; F. Riacho; G. Reservatório (açude) durante o período chuvoso. 


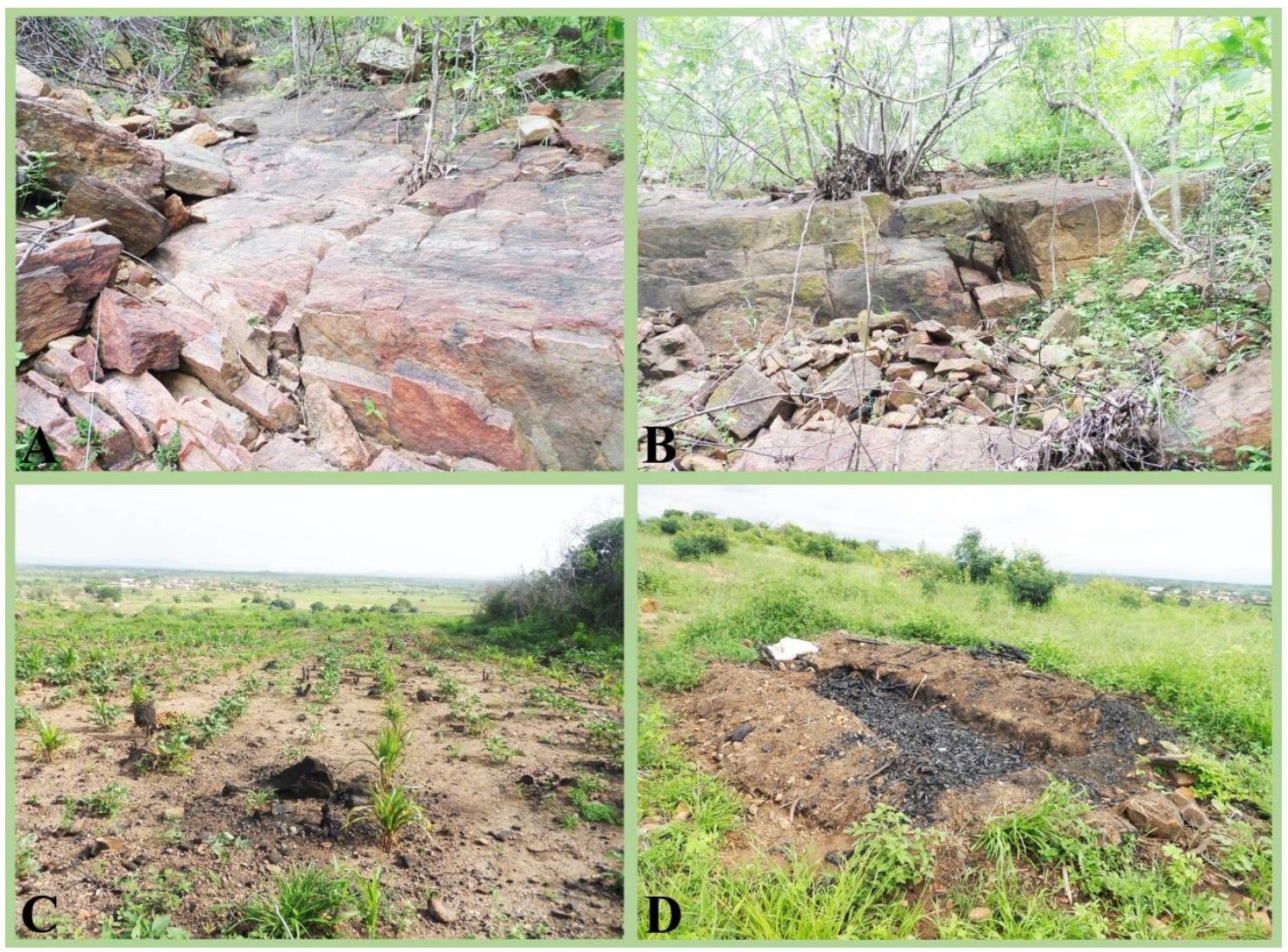

Figura 3. Afloramentos rochosos e danos ambientais ocasionados na Serra: A-B. Trechos com formações rochosas que seguem o percurso de riachos; C. Áreas agricultáveis; D. Local de produção de carvão (forno de carbonização).

\section{Coleta, análise e interpretação de dados}

A coleta de material botânico, fértil (flores e/ou frutos), ocorreu por meio de expedições quinzenais à Serra da Arara, iniciadas no período de fevereiro de 2015 a julho de 2016, perpassando as estações chuvosas e de maior escassez hídrica, permitindo assim uma comparação da diversidade de espécies encontradas nas respectivas fases (Figura 4A).

Foram realizadas cerca de 30 expedições intensificadas semanalmente no período chuvoso compreendendo os meses de janeiro, fevereiro, março e abril; onde foram feitas observações e anotações sobre as variações morfológicas das espécies de Rubiaceae, tais como hábito, frequência na área, nome popular, presença ou ausência de visitantes florais, coloração de flores e frutos, aromas, presença de resinas e tipo de solo em que se encontravam.

Após a coleta, o material passou pelo processo de herborização (Figura 4B) adotando-se as técnicas usuais descritas na literatura (Gadelha Neto et al. 2013). O material coletado foi incorporado na coleção científica do Herbário Lauro Pires Xavier (JPB), da Universidade Federal da Paraíba (UFPB), com duplicatas enviadas para a coleção didática do Laboratório de Botânica, do Centro de Formação de Professores (CFP), da Universidade Federal de Campina Grande (UFCG).

As análises morfológicas (Figura 4C) das espécies foram feitas com o auxílio de estereomicroscópio disponibilizado no Laboratório de Botânica da UFCG e a terminologia estando de acordo com bibliografia especializada (Vidal \& Vidal 2003; Souza et al. 2013). Com base nas observações em campo e do material herborizado, foram elaboradas descrições morfológicas detalhadas que subsidiaram a construção de uma chave analítica para separação das espécies ocorrentes na Serra da Arara. Além disso, os dados apresentados na caracterização da família estão de acordo com as espécies encontradas na área de estudo, sem 
complementações de caracteres comuns nos demais taxa do grupo encontrados na literatura especializada.

Os resultados trazem além das descrições das espécies, informações de distribuição geográfica extraídas da base de dados Flora do Brasil (2020: em construção), das consultas nas etiquetas do material depositado no Herbário JPB (Figura 4D) e/ou referencial teórico (e.g., Pessoa \& Barbosa 2012; Pereira \& Pereira 2018; Nemopuceno et al. 2018). Destaca-se a variação dos períodos férteis obtidos a partir das observações de campo, indicando o tempo de floração e frutificação dos seus representantes. Também são apresentados comentários ecológicos, nome popular, frequência na área e aplicação 'medicinal' das espécies, quando conhecidos.

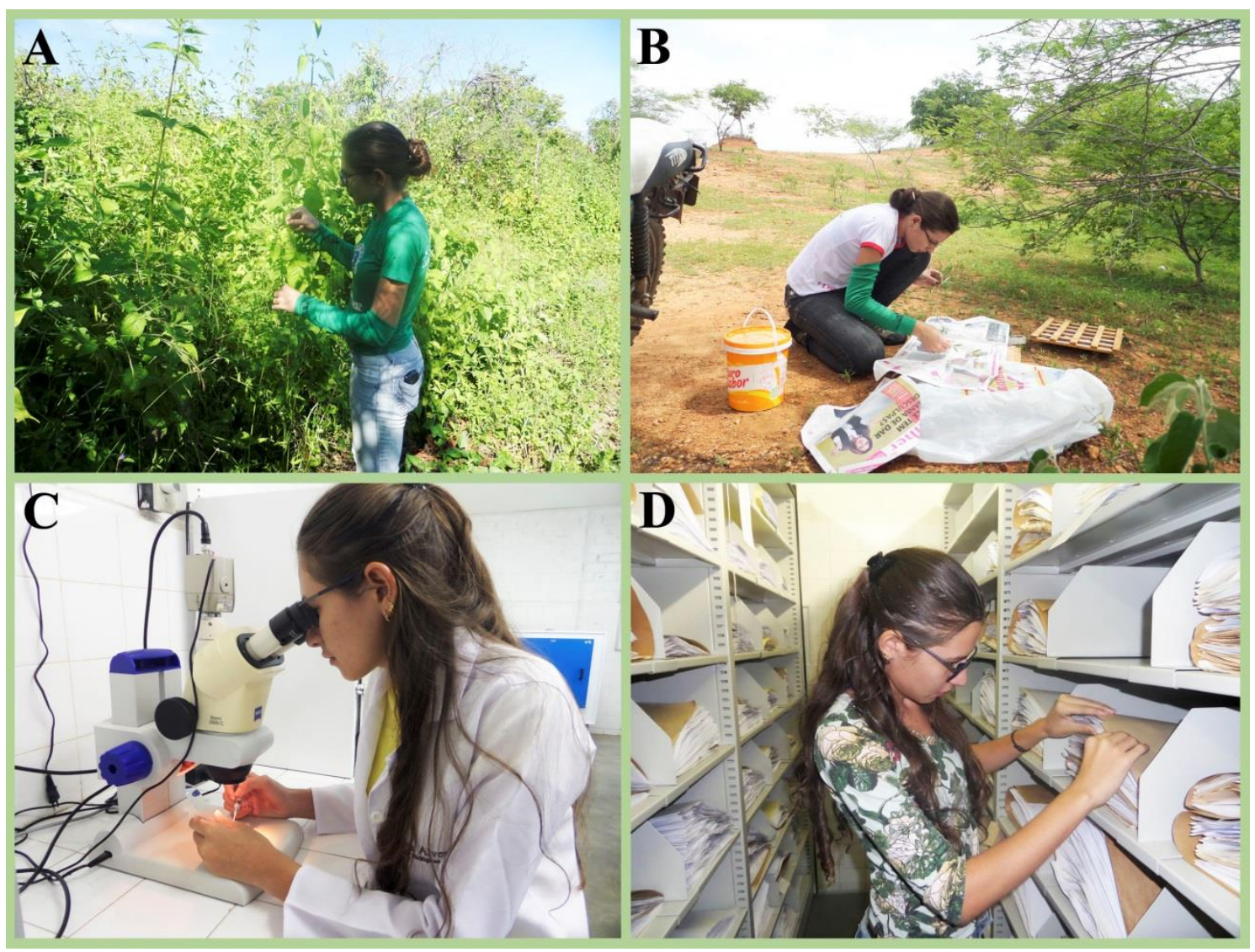

Figura 4. Fases de coleta em campo até análise morfológica do material: A. Coleta; B. Prensagem (herborização); C. Análise morfológica em estereomicroscópio; D. Consulta e análise de material botânico no herbário JPB.

\section{Resultados e Discussão}

Foram registrados na Serra da Arara, sete gêneros e 10 espécies, distribuídos em duas subfamílias Ixoroideae (2) e Rubioideae (8), sendo Borreria G. Mey. o mais representativo com três espécies [Borreria brownii (Rusby) Standl., B. scabiosoides Cham. \& Schltdl. e B. spinosa (L.) Cham. \& Schltdl..], seguido de Tocoyena Aubl., com duas [Tocoyena formosa (Cham. \& Schltdl.) K. Schum. e T. sellowiana (Cham. \& Schltdl.) K. Schum.]. Os demais gêneros apresentaram uma única espécie cada, Hexasepalum apiculata Willd. ex Roem. \& Schult.; Oldenlandia corymbosa L.; Richardia grandiflora (Cham. \& Schltdl.) Steud., Spermacoce tenuior L. e Staelia virgata (Link ex Roem. \& Schult.) K. Schum.

Das espécies encontradas na Serra da Arara, a grande maioria é de hábito herbáceo $(73 \%)$ ou arvoreta $(18 \%)$ e num menor percentual, herbáceo sublenhoso (9\%). Evidenciando assim, a maior representatividade da subfamília Rubioideae, principalmente membros da tribo Spermacoceae (tipicamente herbáceas), o que corrobora com os dados obtidos por Pereira \& Pereira (2018), no estudo realizado com a família em uma área de Caatinga do sertão paraibano. 
É destaque no trabalho Oldenlandia corymbosa L. por ser uma nova ocorrência para o estado da Paraíba, informação fundamentada em consultas a base de dados online, material depositado em herbário e na literatura especializada.

\section{Rubiaceae Juss. Genera Plantarum: 196. 1789.}

Caracterização: Plantas monoicas, arvoretas, subarbustos ou ervas, eretas ou prostradas. Caule cilíndrico, anguloso ou tetrangular, lenticelados ou não, glabro ou piloso. Estípulas livres ou conatas formando bainha, interpeciolar, inteira ou fimbriada, persistente ou caduca, glabra ou pilosa. Folha simples, oposta dística ou cruzada, séssil, pseudopeciolada ou peciolada, elíptica, ovada, obovada, linear, largo-lanceolada ou estreito elíptica, membranácea, coriácea ou cartácea, glabra ou pilosa. Inflorescência em glomérulo, dicásio ou fascículo, terminal ou axilar, séssil ou pedunculada, brácteas involucrais ou foliáceas, bractéolas florais presentes ou ausentes. Flor séssil ou pedicelada, diclamídea, andrógina, glabra ou pilosa 4-6 meras, actinomorfa, botão floral oblongo ou obovado, ápice agudo ou semicircular, glabro ou piloso. Cálice gamossépalo, subulado ou campanulado, lacínios iguais ou desiguais entre si, glabro ou piloso. Corola gamopétala, ciatiforme, infundibuliforme ou hipocreteriforme, prefloração valvar ou contorta. Estames dialistêmones, isostêmones, alternos aos lobos da corola, exsertos ou inclusos. Ovário ínfero, bilocular ou plurilocular, uniovular ou multiovular, placentação axial ou basal. Estigma inteiro, bilobado ou trífido. Fruto seco ou carnoso, deiscente ou indeiscente, capsula septícida ou loculicida, esquizocarpo ou baga, oblongo ou globoso, piloso, hirsuto ou glabro. Semente oblonga, elipsoide, piramidal ou discoide a obovada, sulcos transversais na face dorsal ou não, sulco longitudinal na face ventral com ou sem estrofíolos. Os caracteres diagnósticos de Rubiaceae são ilustrados na Figura 5.

\section{Chave de identificação das espécies de Rubiaceae ocorrentes na Serra da Arara}

1. Plantas lenhosas; arvoretas; estípulas inteiras, caducas; dicásios terminais; corola hipocrateriforme; frutos carnosos

2. Lâmina foliar tomentosa em ambas as faces; opacas na face superior; cálice 5-denticulado; fruto híspido.................................................................................................................................................................9. Tocoyena formosa

2'. Lâmina foliar glabra em ambas as faces, lustrosa na face superior; cálice 6-denticulado; fruto glabro 10. Tocoyena sellowiana

1'. Plantas herbáceas; eravas; estípulas fimbriadas, persistentes; glomérulos terminais ou axilares, fascículos ou flores isoladas, axilares ou terminais; corola ciatiforme ou infundibuliforme; frutos secos

3. Fruto capsular, deiscente

4. Flor pedicelada, ovário pluriovular; cápsula loculicida ..5. Oldenlandia corymbosa

4'. Flor séssil, ovário uniovular, cápsula septicida,

5. Folha oposta cruzada a pseudoverticilada; tubo da corola em forma de campana. 3. Borreria spinosa

5'. Folha oposta; tubo da corola afunilado ou cilíndrico

6. Fruto com deiscência transverso oblíqua 8. Staelia virgata 6 '. Fruto com deiscência longitudinal

7. Margem do limbo foliar ciliada; fruto obovoide a linear.

7'. Fruto oblongo a ovado; margem do limbo foliar não ciliada

7. Spermacoce tenuior

8. Folha peciolada, elíptica a ovada; corola ciatiforme; semente com sulcos transversais na face dorsal.

...1. Borreria brownii 8'. Folha séssil, lanceolada a largo lanceolada; corola infundibuliforme; semente com sulcos transversais ausentes na face dorsal 2. Borreria scabiosoides

3'. Fruto esquizocárpico

9. Dois mericarpos; ápice do botão floral obtuso; flores tetrâmeras; ovário bilocular; semente com sulco ventral em forma de Y. 4. Hexasepalum apiculata 9'. Três mericarpos; ápice do botão floral semicircular; flores hexâmeras; ovário trilocular; semente com sulco ventral longitudinal.

6. Richardia grandiflora 

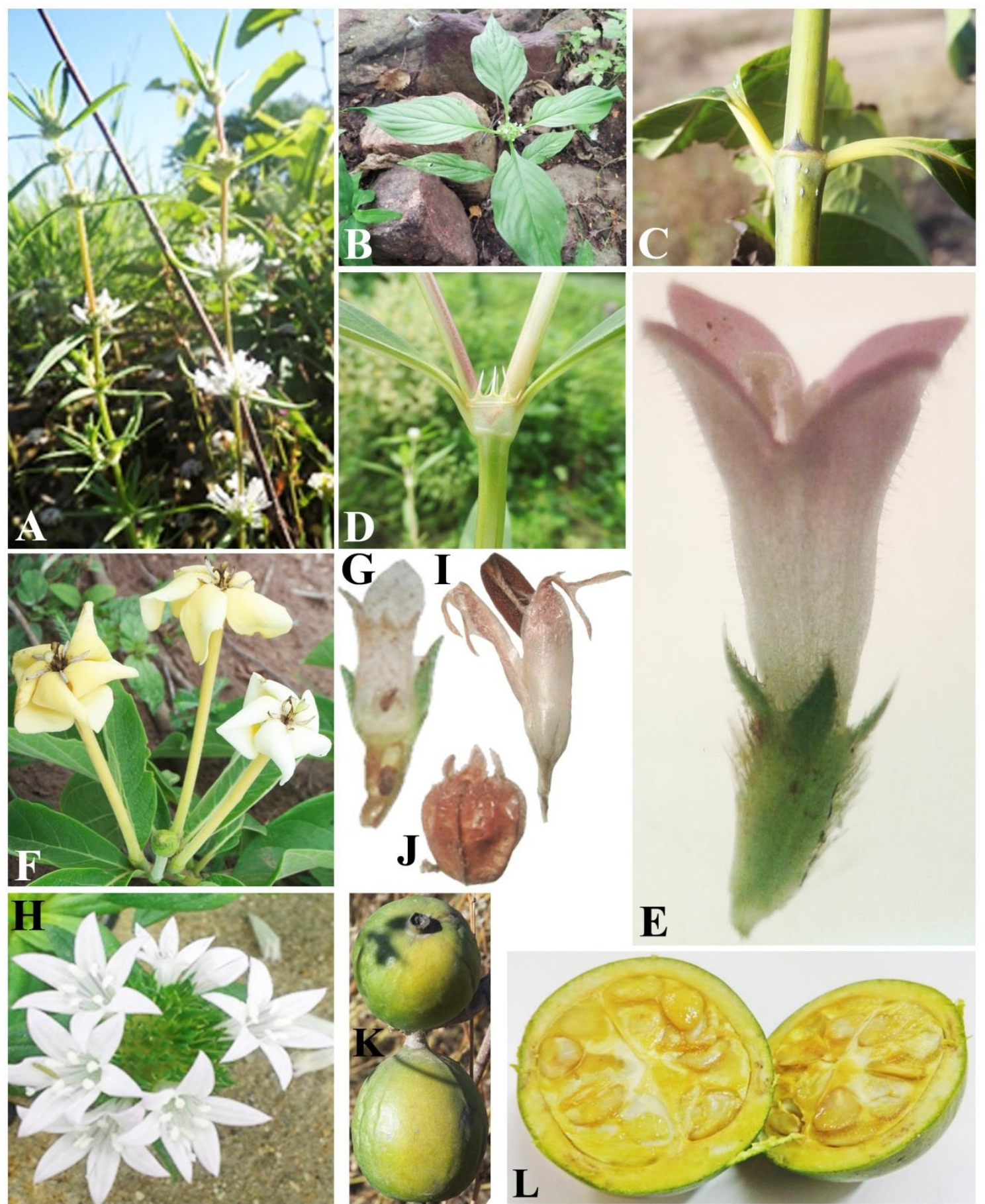

Figura 5. Características diagnósticas dos representantes da família Rubiaceae: A. Folhas pseudoverticiladas; B. Folhas opostas cruzadas; C. Estípula inteira; D. Estípula fimbriada; E-F. Corola gamopétala; G. Ovário ínfero; H. Estames isostêmones; I. Fruto seco esquizocarpo deiscente; J. Fruto seco indeiscente; K. Fruto carnoso baga; L. Corte transversal de fruto carnoso com a distribuição das sementes.

1. Borreria brownii (Rusby) Standl., Publ. Field Mus. Nat. Hist., Bot. Ser. 7: 333. 1931

Figura 6A-J

Caracterização: Erva ereta, $18-70 \mathrm{~cm}$ alt. Caule cilíndrico a tetrangular, verde a vináceo, não lenticelado, glabro na base e piloso no ápice, entrenós 1-1.6 cm. Bainha estipular 0.3-0.5 $\times$ 0.1-0.4 cm, fimbriada, 3-7 fímbrias, persistentes, glabra externamente, sem coléteres. Folha oposta cruzada, peciolada; lâmina 3.8-6.4 × 1.3-3.6 cm, elíptica a ovada, base atenuada a acuneada, ápice agudo a cuspidado, margem inteira, membranácea, pilosa na face superior e nas 
nervuras da inferior, venação camptódroma a eucamptódroma, nervuras principal e secundarias proeminentes na face inferior, 4-9 pares de nervura , verde, pecíolo $6.3-10 \times 1.2-2.5 \mathrm{~mm}$, verde, glabro. Glomérulo, 0.4-1.2 $\times$ 0.7-1.5 cm, terminais e axilares, séssil, 10-23 flores, 4 brácteas foliáceas, 3.4-8.4 × 1.2-3.5 cm, elíptica a ovada, verdes, pilosas nas faces superior e inferior. Flor séssil, glabra; botão floral 2.8-3.9 × 1-2 mm, obovado, ápice agudo a semicircular, piloso apenas no ápice. Cálice subulado, 4.7-4.9 × 1.3-2.2 mm, 4 lacínios, desiguais, verde, piloso. Corola ciatiforme, branca, prefloração valvar, tubo 2.9-3.7 × 1-1.4 mm, ereto, cilíndrico, glabro externamente e internamente, 4 lobos, 1-1.7 $\times 2-3 \mathrm{~mm}$, ápice agudo, piloso externamente e glabro internamente. Estames 4, exsertos, presos a fauce; filetes 1-1.5 mm comp., glabros; anteras $1 \mathrm{~mm}$, oblongas, azuladas, glabras. Hipanto 1-4 $\mathrm{mm}$ comp., oblongo, glabro. Ovário bilocular, uniovular, placentação axial; estilete 2-4.5 $\mathrm{mm}$ comp., cilíndrico, glabro; estigma inteiro, papiloso. Fruto seco, cápsula septicida, 2.8-7 × 1.5-3 mm, oblongo a ovado, 2 linhas de deiscência, cálice persistente, verde quando imaturo, marrom quando maduro, piloso no ápice. Semente oblonga, $2.5-5 \times 1.2-1.8 \mathrm{~mm}$, exotesta foveada, sulco longitudinal na face ventral com estrofíolos, sulcos transversais na face dorsal, castanha a marrom.

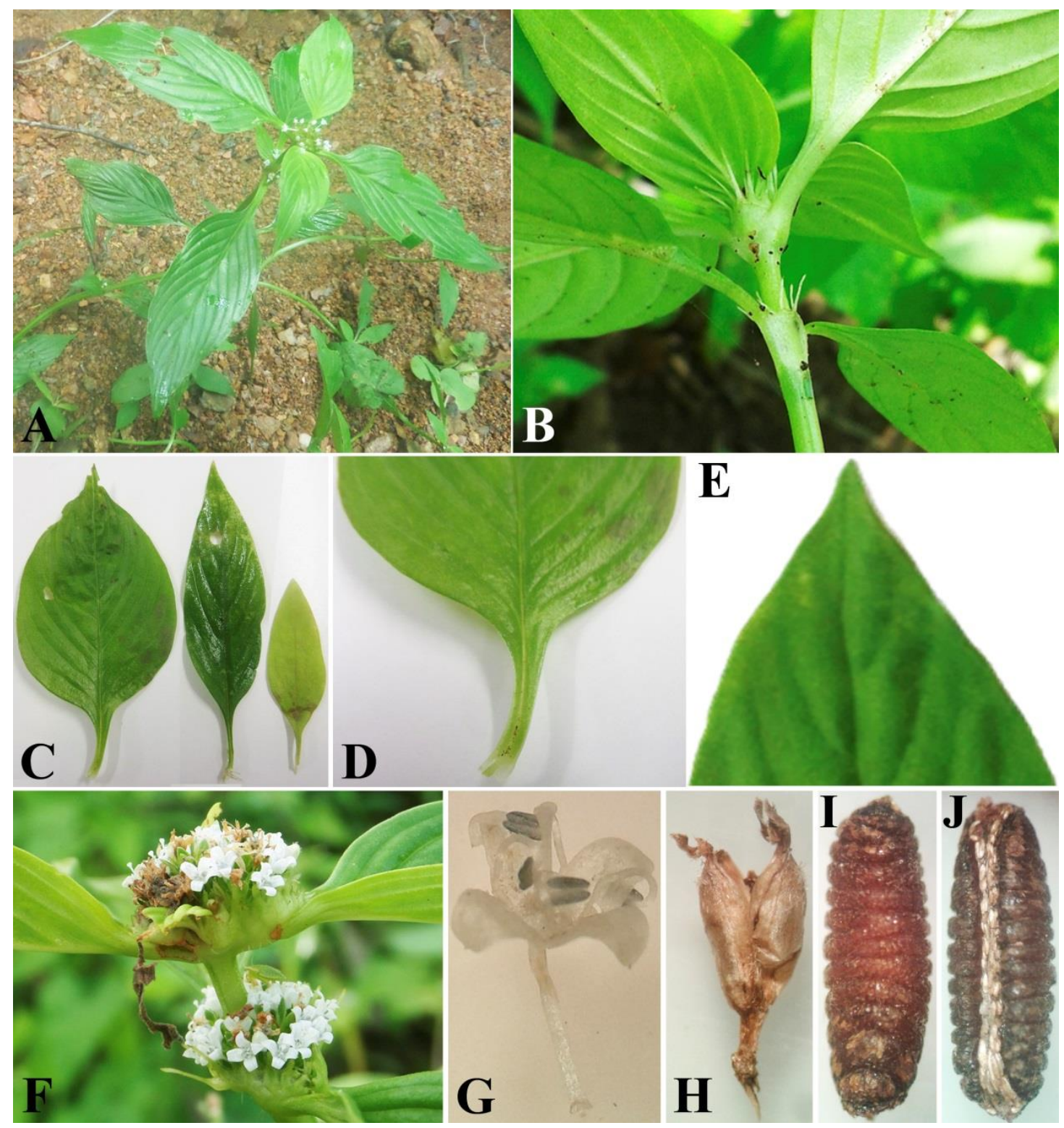

Figura 6. Borreria brownii (Rusby) Standl.: A. Hábito; B. Estípulas interpeciolares fimbriadas; C. variação do limbo - ovada a elíptica; D. Base atenuada a acuneada; E. Ápice agudo; F. Inflorescências em glomérulos; G. Corola ciatiforme; H. Cápsula septícida; I. Semente com sulcos transversais - face dorsal; J. Semente com estrofíolos ao longo do sulco longitudinal - face ventral. 
Material examinado: BRASIL: Paraíba: Santa Helena, Serra da Arara, Várzea da Ema 12/IV/2015, fl., A.A. Quaresma 22 (JPB); 09/IV/2016, fl., fr., $A . A$. Quaresma 46 (JPB); 03/VI/2016, fl., fr., $A . A$. Quaresma 61.

Distribuição geográfica: Borreria brownii ocorre no México, Guatemala, Costa Rica, Venezuela, Brasil, Bolívia e Argentina (Cabral \& Bacigalupo 1999; Pessoa \& Barbosa 2012). No Brasil é encontrada no Nordeste (Bahia, Ceará, Maranhão, Paraíba, Rio Grande do Norte) e Centro-oeste (Goiás) abrangendo os domínios fitogeográficos da Caatinga e do Cerrado (Pessoa \& Barbosa 2012; Flora do Brasil 2020 - em construção). Para a Paraíba há registros até o momento de sua ocorrência, no município de Monteiro (Cariri Paraibano), tendo sido coletada em áreas de Caatinga sensu stricto (Pessoa \& Barbosa 2012).

Considerações: Encontrada na área de estudo em lugares úmidos, tais como, ao longo de cursos d'água (riachos), borda da mata fechada e/ou ambientes perturbados, como plantações agrícolas. Coletada florida e frutificada de abril a junho, que correspondeu ao período chuvoso na região. Pode ser diferenciada das demais espécies estudadas, pela forma da corola do tipo ciatiforme e numerosos sulcos transversais da semente.

\section{Borreria scabiosoides Cham. \& Schltdl., Linnaea 3: 318. 1828.}

Figura 7A-J

Caracterização: Erva ereta a prostrada, $30-50 \mathrm{~cm}$ alt. Caule cilíndrico, verde a vináceo, não lenticelados, glabro, entrenós 4-10 cm. Bainha estipular 0.5-0.6 $\times 0.35-0.7 \mathrm{~cm}$, fimbriada, 3-7 fímbrias, persistentes, glabra externamente, coléteres no ápice das fímbrias. Folha oposta cruzada, séssil; lâmina 2.5-7.5 × 0.65-1.8 cm, lanceolada a largo lanceolada, base atenuada, ápice agudo a acuminado, margem inteira, membranácea, glabra na face superior e com dentículos na face inferior ao longo das nervuras, venação camptódroma, nervura principal proeminente na face inferior, 3-6 pares de nervuras secundárias, verde. Glomérulo, $1.3-3 \times 1.15-2.8 \mathrm{~cm}$, terminal, séssil, 15-50 flores, 2 brácteas foliáceas, $4.7-5.5 \times 0.8-1 \mathrm{~cm}$, lanceoladas, verde, glabra na face superior e tricomas nas nervuras da face inferior, 1-2 bractéolas foliáceas, 1.6-4.6 $\times$ $0.3-0.6 \mathrm{~cm}$, lanceoladas, verdes, glabra na face superior e tricomas nas nervuras da face inferior. Flor séssil, pilosa externamente e internamente; botão floral $4-5 \times 1.5-2.5 \mathrm{~mm}$, oblongo, ápice agudo, piloso na porção superior. Cálice subulado, 2.5-3 × 0.8-1 mm, 4 lacínios, iguais, branco na base e verde no ápice, piloso externamente e glabro internamente. Corola infundibuliforme, branca, prefloração valvar, tubo 3-5 × 1-2.5 mm, ereto, cilíndrico, piloso externamente e internamente com um anel de tricomas, 4 lobos, $0.3-1 \mathrm{~mm}$, ápice triangular, piloso externamente e glabro internamente. Estames 4, exsertos; filetes $1 \mathrm{~mm}$ comp., glabros; anteras 1-1.2 mm, oblongas, azuladas, glabras. Hipanto 1-2 mm comp., oblongo, glabro. Ovário bilocular, uniovular, placentação basal; estilete $3-5 \mathrm{~mm}$ comp., cilíndrico, glabro; estigma bilobado, papiloso. Fruto seco, cápsula septicida, 3.8-7 × 1.6-2.1 mm, oblongo, 2 mericarpos, com 2 linhas de deiscência, cálice persistente, verde quando imaturo, marrom a amarelo quando maduro, piloso no ápice. Semente oblonga, 2.5-3.2 × 1-1.2 mm, exotesta foveolada, sulco ventral longitudinal com estrofíolos, face dorsal ruminada, marrom.

Material examinado: BRASIL: Paraíba: Cajazeiras, Serra da Arara, Sítio Serragem, 19/VII/2015, f1., A.A. Quaresma 29; 09/IV/2016, f1., A.A. Quaresma; A.S. Santos 47(JPB). 03/VI/2016, fl., fr., A.A. Quaresma; A. S. Santos 63(JPB).

Distribuição geográfica: Borreria scabiosoides tem distribuição Neotropical, ocorrendo no Equador, Venezuela, Argentina, Bolívia e Brasil, neste último ocorre nas regiões Norte, Nordeste e Centro-oeste, nos domínios da Amazônia, Caatinga, Cerrado e Mata Atlântica (Andersson 1992; Cabral et al. 2011; Flora do Brasil 2020 - em construção). No estado da Paraíba, encontra-se desde áreas litorâneas, tal como elencada por Pereira \& Barbosa (2006) no município de 
Mamanguape, até regiões mais secas, no Cariri Paraibano, em Monteiro por Pessoa \& Barbosa (2012), no Sertão Paraibano, em Sousa (Gadelha Neto \& Barbosa 2007) e na Serra do Bongá, vertente Monte Horebe-São José de Piranhas (Pereira \& Pereira 2018).
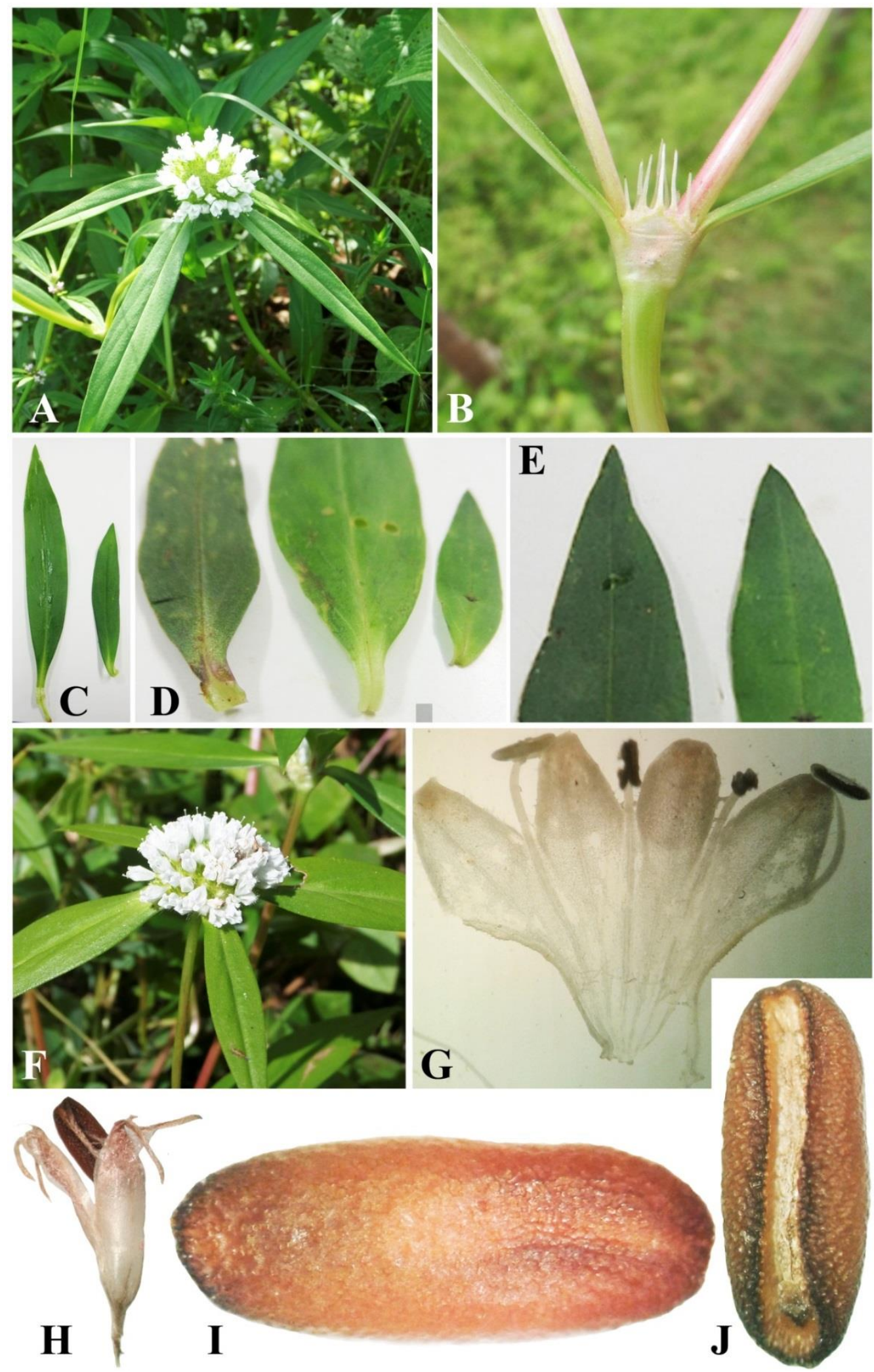

Figura 7. Borreria scabiosoides Cham. \& Schltdl.: A. Ramo florífero; B. Estípulas interpeciolares, fimbriadas; C. Variação do limbo-lanceolada a largo-lanceolada; D. Base atenuada; E. Ápice agudo; F. Inflorescência em glomérulo; G. Corola aberta com estames exsertos; H. Cápsula septícida; I. Semente ruminada (face dorsal); J. Semente com sulco longitudinal com estrofíolos (face ventral). 
Considerações: Na Serra da Arara foi coletada em lugares úmidos, no entorno de lagoas, açudes e riachos como também no interior de ambientes temporariamente alagados, caracterizando uma erva palustre (Pessoa \& Barbosa 2012). Florescendo e frutificando de março a julho que compreendem os meses do período chuvoso. Distinguindo das espécies de Borreria, na área, pelo caule cilíndrico robusto, folhas lanceoladas a largo lanceoladas e presença de coléteres no ápice das fímbrias. É popularmente conhecida como "cabeça de velho" tal como Borreria spinosa, e utilizada, segundo moradores, como alimento para bovinos e equinos.

\section{Borreria spinosa (L.) Cham. \& Schltdl., Linnaea 3(4): 340 (1828), nom. inval.}

\section{Figura 8A-J}

Caracterização: Erva ereta, 20-50 cm alt. Caule tetrangular, verde a vináceo, não lenticelados, glabro, piloso nos ângulos, entrenós 3.6-6.2 cm. Bainha estipular 2.5-6 × 2.8-9 mm, fimbriada, 7-10 fimbrias, persistentes, glabra, sem coléteres. Folha oposta ou pseudoverticilada, séssil; lâmina 2.8-8.2 × 2.15-3 cm, elíptica a largo-lanceolada, base acunheada a truncada, ápice agudo, margem inteira, membranácea, pilosa nas faces superior e inferior, venação eucamptrodoma, nervura principal com papilas e secundárias proeminentes na face inferior, 4-7 pares de nervuras secundárias, verde. Glomérulo, $2.8-3.5 \times 2.5-3 \mathrm{~cm}$, terminal ou axilar, séssil, $60-120$ flores, 2-8 brácteas foliáceas, 2.1-4.8 $\times 0.7-2.4 \mathrm{~cm}$, elípticas a lanceoladas, verdes, hirsuta na face superior e inferior com papilas ao longo das nervuras. Flor séssil, glabra; botão floral 2.5-2.6 $\times$ 1.6-1.9 mm, ovado, ápice agudo, piloso no ápice. Cálice subulado, 1-2 × 0.8-1 mm, 2 lacínios, iguais, verde, piloso externamente. Corola infundibuliforme, branca, prefloração valvar, tubo 2-2.1 $\times 1.7-2.2 \mathrm{~mm}$, ereto, em forma de campana, glabro externamente e piloso internamente, 4 lobos, menores que $1 \mathrm{~mm}$, ápice agudo, externamente glabro e internamente com um anel de tricomas na inserção dos filetes. Estames 4, exsertos, presos a fauce; filetes 1-1.2 mm, glabros; anteras $0.7-1 \mathrm{~mm}$, oblongas, brancas, glabras. Hipanto $1.5-3.2 \mathrm{~mm}$ compr., oblongo, glabro. Ovário bilocular, uniovular, placentação axial; estilete 1-2 $\mathrm{mm}$ comp., cilíndrico, glabro; estigma bilobado, papiloso. Fruto seco, cápsula septicida, 2-4 × 1-1.8 mm, oblonga, com 2 linhas de deiscência, cálice persistente, verde quando imaturo, marrom quando maduro, piloso no ápice. Semente elipsoide, $1.2-3 \times 0.6-0.8 \mathrm{~mm}$, sulco ventral com estrofíolos nas bordas e no interior, face dorsal côncava ruminada, castanha.

Material examinado: BRASIL: Paraíba: Santa Helena, Serra da Arara, Várzea da Ema, 24/III/2015, fl., A.A. Quaresma 18 (JPB); 16/IV/2016, fl., A.A. Quaresma; M.S. Pereira; W.P. Araújo 51 17/IV/2015, fl., fr., A.A. Quaresma; A.S. Santos 53 (JPB).

Distribuição geográfica: Borreria spinosa apresenta distribuição nas Américas, do México a Argentina (Cabral et al. 2011). No Brasil há registros para todas as regiões geográficas sendo que no Norte ocorre apenas em Tocantins. Sua abrangência contempla os domínios fitogeográficos da Amazônia, Caatinga, Cerrado e Mata Atlântica (Flora do Brasil 2020 - em construção).

Considerações: Na região, foi encontrada no entorno da Serra, áreas agricultáveis, ao longo das trilhas de acesso ao local de estudo e em ambientes antropizados. Floresce e frutifica nos meses de março a junho, acompanhando o período chuvoso, já que há maior quantidade de água favorecendo o desenvolvimento das suas fases reprodutivas. Diferencia-se das demais espécies de Borreria diagnosticadas na Serra da Arara, pelas folhas pseudoverticiladas, número de brácteas foliáceas (podendo atingir até oito) e sementes com estrofiolos nas bordas do sulco ventral. É conhecida popularmente, na região, como "cabeça de velho" sendo visitada por abelhas e formigas (Pereira \& Pereira 2018). A referida espécie apresenta características morfológicas muito semelhantes a Borreria capitata diferenciando desta pelo número de brácteas ( 8 vs 4 ), número de lacínios do cálice ( 2 vs 4 ) e pilosidade do fruto (piloso no ápice vs escabro). 


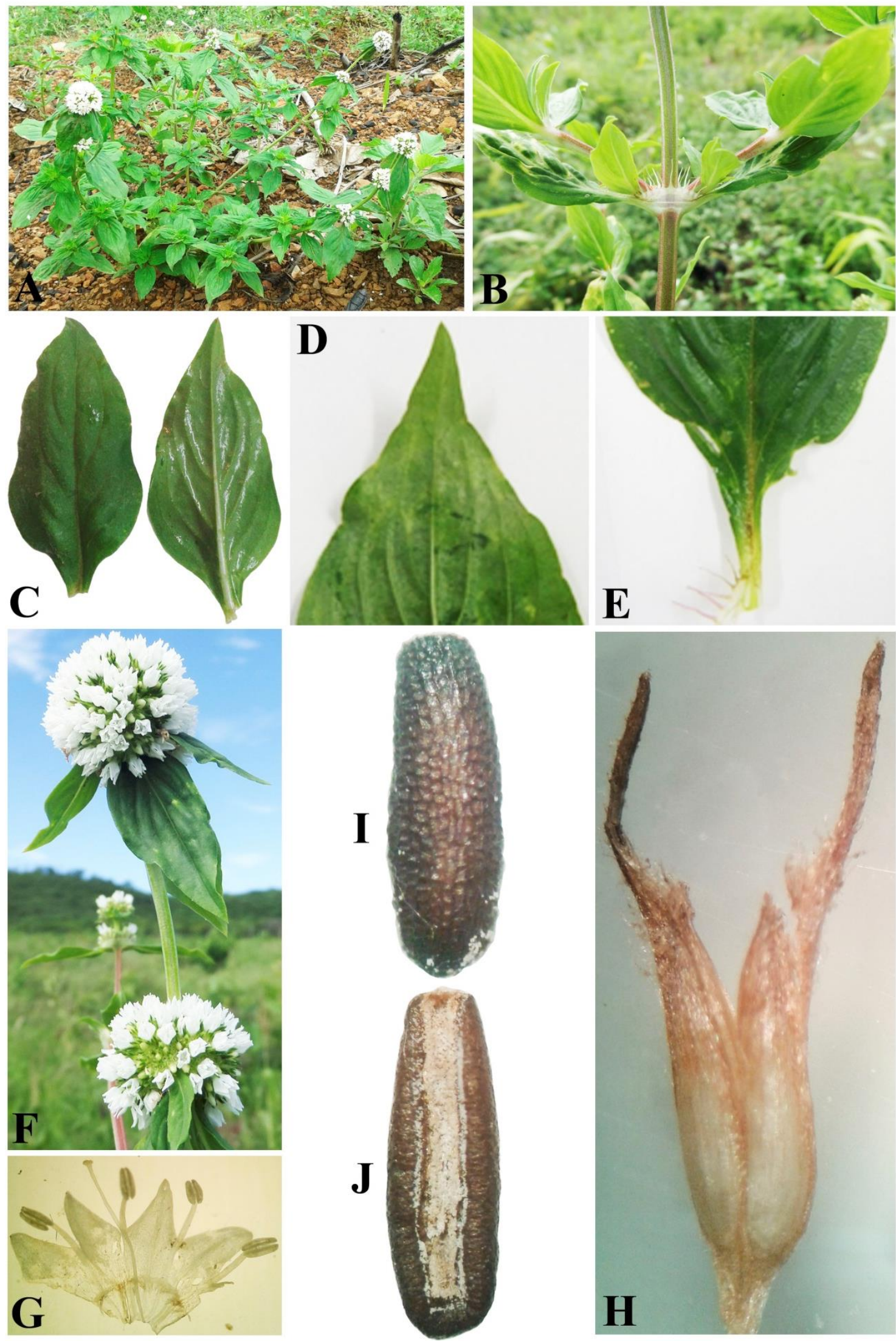

Figura 8. Borreria spinosa (L.) Cham. \& Schltdl.: A. Erva ereta; B. Estípula interpeciolar, fimbriada; C. Limbo elíptico; D. Ápice agudo; E. Base acunheada; F. Inflorescência em glomérulos capituliformes; G. Estames isostêmones, inseridos na fauce; $\mathbf{H}$. Cápsula septícida; I. Semente ruminada-face dorsal; J. Semente com estrofíolos na borda e no interior do sulco longitudinal-face ventral. 
4. Hexasepalum apiculatum (Willd. Ex Roem. \& Schult.) Delprete \& JHKirkbr., J. Bot. Res. Inst. Texas 9(1): 104 (2015).

\section{Figura 9A-J}
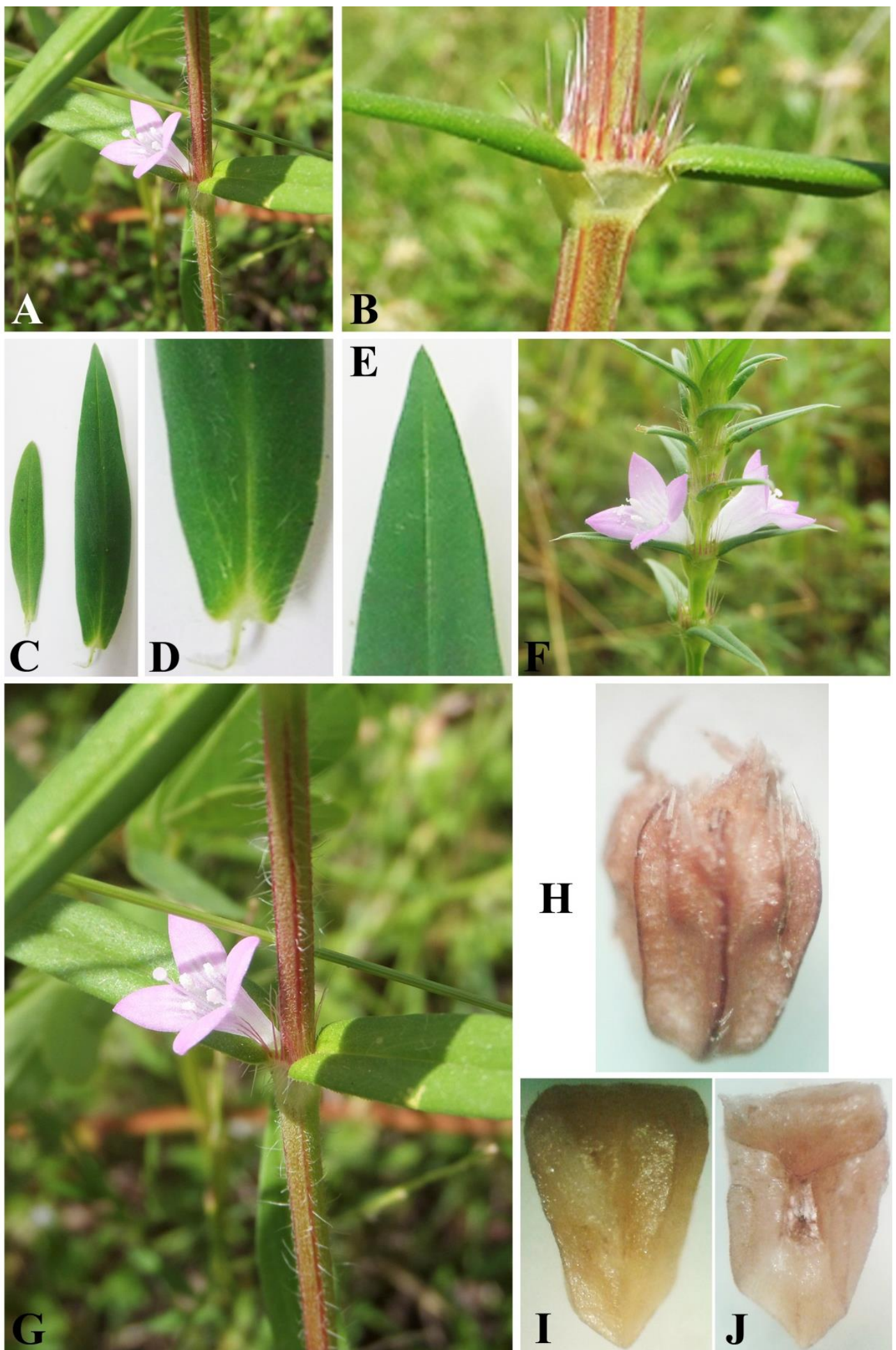

Figura 9. Hexasepalum apiculatum (Willd. ex Roem. \& Schult.) Delprete \& J.H.Kirkbr.: A. Ramo florido B. Detalhe do caule tetrangular e estípula fimbriada; C. Variação do limbo- lanceolada a estreito elíptica; D. Base truncada; E. Ápice agudo; F. Detalhe da inflorescência; G. Detalhe da corola e estames exsertos; H. Esquizocarpo; I. Semente estriada (face dorsal); J. Semente com sulco em forma de Y com estrofíolos. 
Caracterização: Erva ereta, 15-60 cm alt. Caule tetrangular, verde a vináceo, não lenticelados, hirsuto, entrenós $0.4-2.2 \mathrm{~cm}$. Bainha estupular $0.3-0.7 \times 0.2-0.6 \mathrm{~cm}$, fimbriada, 7-15 fímbrias, persistente, hirsuta, sem coléteres. Folha oposta cruzada, séssil, lâmina $1.4-5.2 \times 0.8-2.4 \mathrm{~cm}$, lanceolada a estreito elíptica, base truncada, ápice agudo, margem inteira, membranácea, escabra em ambas as faces, venação eucamptódroma, nervura principal proeminente na face inferior, 3-6 pares de nervura secundária, verde. Glomérulo 0.6-0.8 $\times 0.7-0.9 \mathrm{~cm}$, axilar, séssil, 2-6 flores, 2 brácteas foliáceas, $1.2-4.5 \times 0.5-1.7 \mathrm{~cm}$, linear a estreito elíptica, verde, pilosa nas faces superior e inferior. Flor séssil, pilosa; botão floral 1.5-3.5 × 1-3 mm, oblongo, ápice obtuso, piloso. Cálice subulado, $2-4 \times 0.8-1.5 \mathrm{~mm}, 4$ lacínios desiguais, verde, hirsuto. Corola infundibuliforme, lilás, prefloração valvar, tubo 1.7-6 × 1-1.5 mm, ereto, cilíndrico, piloso externamente e internamente com um anel de tricomas na base, 4 lobos, $0.5-2 \times 0.3-1.2 \mathrm{~mm}$, ápice agudo, pilosos eternamente e internamente. Estames 4, exsertos, presos a fauce; filetes 0.8-1.2 mm comp, glabros; anteras $0.5-1 \mathrm{~mm}$, oblongas, branca, glabra. Hipanto $1.2-1.8 \mathrm{~mm}$ comp., obovado, glabro. Ovário bilocular, uniovular, placentação basal; estilete, 2-10 mm comp., cilíndrico, glabro; estigma capitado, papiloso. Fruto seco, esquizocarpo, 0.6-3.5 × 0.4-1.5 cm, oblongo a obovado, cálice persistente, 2 mericarpos, indeiscentes, mas que se separam, verde quando imaturo e marrom quando maduro, piloso no ápice. Semente $2-3 \times 1-1.5 \mathrm{~cm}$, obovada, plano convexas, sulco ventral em forma de Y com estrofíolos, face dorsal estriada, amarela a marrom, muricada.

Material examinado: BRASIL: Paraíba: Santa Helena, Várzea da Ema, Serra da Arara, 03/II/2015, fl., fr., A.A. Quaresma; W.S. Teixeira 17 (JPB). 20/III/2016, fl., A.A. Quaresma 44. 03/VI/2016, fl., fr., A.A. Quaresma; A.S. Santos 62 (JPB). São João do Rio do Peixe, Sítio Pé de Serra, Serra da Arara, 13/II/2015, fl., fr., A.A. Quaresma 12.

Distribuição geográfica: Hexasepalum apiculatum apresenta distribuição na região neotropical, do México ao Paraguai (Andersson 1992), ocorrendo em todas as regiões do Brasil e domínios fitogeográficos (Flora do Brasil 2020 - em construção). Na Paraíba ocorre em municípios de regiões litorâneas (Mamanguape) e do Cariri (Cabaceiras, Caturité, Monteiro, São João do Cariri, São João do Tigre, São João do Cordeiros, Serra Branca).

Considerações: Na Serra da Arara, foi coletada com flor e fruto, nos meses de fevereiro a junho, em lugares úmidos e secos, de variadas altitudes, evidenciando a alta frequência da mesma na área, a partir das observações realizadas, durante as excussões de campo, para coleta de material fértil. Os moradores próximos da serra a consideram como espécie invasora, eles realizam o que denominam de "limpa de mato", que consiste na remoção dos indivíduos no ambiente. Ovário uniovular, fruto esquizocarpo e semente com face dorsal estriada a diferencia de Oldenlandia corymbosa L.

5. Oldenlandia corymbosa L., Fl. bras. 6(6): 273, 1889.

\section{Figura 10A-K}

Caracterização: Erva decumbente, $4.5-20 \mathrm{~cm}$ alt. Caule tetrangular, verde a vináceo, não lenticelados, hirsuto, entrenós $0.4-1.7 \mathrm{~cm}$. Bainha estipular $0.2-0.3 \times 0.25-0.1 \mathrm{~cm}$, fimbriada, 10-13 fimbrias, persistentes, externamente glabra, sem coléteres. Folhas opostas cruzadas, séssil; lâmina 1.2-1.6 $\times$ 0.4-0.5 cm, elíptica a lanceolada, base cuneada a atenuada, ápice agudo a mucronado, margem inteira, membranácea, pilosa na face superior e glabra na face inferior, venação camptódroma a eucamptódroma, nervura principal proeminente na face inferior, 4-5 pares de nervuras secundárias inconspícuas, verde. Fascículo ou flor isolada, 0.7-1.2 × 0.3-0.6 $\mathrm{cm}$, axilar ou terminal, séssil, 2-5 flores, 2 brácteas foliáceas, 1.5-6 $\times 2-4 \mathrm{~mm}$, elíptica a lanceolada, verdes, pilosa na face superior e glabro na face inferior. Flor pedicelada, $0.5-1.2 \mathrm{~cm}$, glabra; botão floral 1-1.5 $\times 0.6-0.8 \mathrm{~mm}$, oblongo, ápice agudo a semicircular, glabro. Cálice subulado, $1-2 \times 0.5-0.9 \mathrm{~mm}, 4$ lacínios, iguais entre si, verde, pubescente. Corola 
infundibuliforme, branca prefloração valvar, tubo $3-4 \times 0.6-0.8 \mathrm{~mm}$, ereto, cilíndrico, glabro externamente e internamente com um anel de tricomas próximo aos lobos, 4 lobos, 1-1.5 $\times$ 0.3-0.5 mm, triangulares, hirsuto externamente e glabro internamente. Estames 4, inclusos, presos a fauce; filetes $0.8^{-1} \mathrm{~mm}$ comp., glabros; anteras $1 \mathrm{~mm}$, oblongas, azuladas, glabras. Hipanto $1 \mathrm{~mm}$ comp., oblongo, glabro. Ovário bilocular, pluriovular, placentação axial; estilete 0.6-1 mm comp., cilíndrico, glabro; estigma bilobado, papiloso. Fruto seco, cápsula loculicida com 2-3 2 1.5-2 mm, subgloboso, deiscência apical, cálice persistente, verde quando imaturo, marrom quando maduro, glabro. Semente piramidal, $0.02-1 \times 0.01-0.08 \mathrm{~mm}$, marrom, faveolada, lisas.
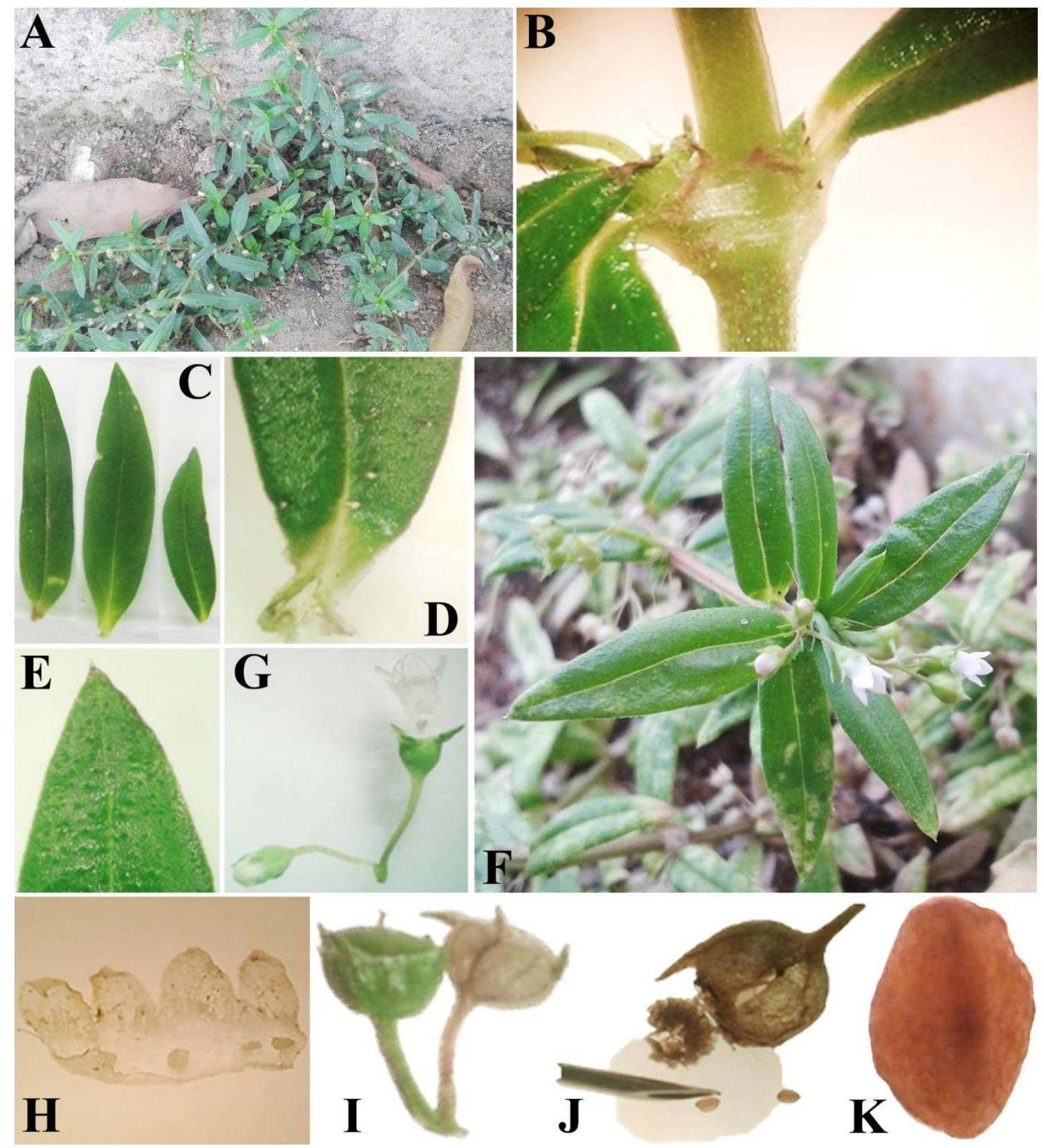

Figura 10. Oldenlandia corymbosa L.: A. Erva prostrada; B. Detalhe da estípula no nó; G. Variação do limbolanceolada a elíptica; D. Base atenuada; E. Ápice agudo; F. Inflorescência em fascículo; G. Flor em botão e aberta; H. Corola dissecada mostrando os estames inclusos; I. Cápsula nos estágios imaturo e maturo; J. Deiscência e liberação das sementes; K. Semente piramidal.

Material examinado: BRASIL: Paraíba: Santa Helena, Várzea da Ema, Serra da Arara, 13/II/2015, fl., fr., A.A. Quaresma 10 (JPB). 23/II/2016, fl., fr., A.A. Quaresma 16. 
Distribuição geográfica: Oldelandia corymbosa tem distribuição Pantropical, no Brasil está representada em todas as regiões geográficas e nos domínios da Amazônia, Caatinga, Cerrado e Mata Atlântica (Jung-Mendaçolli 2007; Flora do Brasil 2020 - em construção). Na Paraíba, não há registro da espécie em nenhum dos estudos taxonômicos ou florísticos realizados, sendo aqui referenciado como nova ocorrência para o estado.

Considerações: Fértil entre os meses de fevereiro e agosto, ocorrendo em solos arenosos e áreas perturbadas, demostrando que a espécie é resistente em períodos secos e ambientes antropizados. Características como inflorescência em fascículo, fruto capsular loculicida com deiscência apical e sementes piramidais a distingue de Hexasepalum apiculata.

\section{Richardia grandiflora (Cham. \& Schltdl.) Steud., Nomencl. Bot. 2, 1: 459, 1840}

\section{Figura 11A-J}

Caracterização: Erva decumbente prostrada, $20-60 \mathrm{~cm}$ alt. Caule anguloso a tetrangular, verde a vináceo, não lenticelado, hirsuto, entrenós $3.8-9.5 \mathrm{~cm}$. Bainha estipular $0.3-0.6 \times 0.3-1.2 \mathrm{~cm}$, fimbriada, 4-9 fímbrias, persistentes, hirsuta externamente, sem coléteres. Folhas opostas cruzadas, séssil; lâmina $2.4-6 \times 0.8-2.1 \mathrm{~cm}$, elíptica a obovada, base atenuada, ápice agudo a acunheado, margem inteira, membranácea, pilosa nas faces superior e inferior, venação camptódroma a eucamptódroma, nervura principal proeminente na face inferior, 4-7 pares de nervura secundária, verde. Glomérulo capituliforme, 1-2.8 $\times 0.8-2.6 \mathrm{~cm}$, terminal, séssil, 10-56 flores, 4 brácteas foliáceas, 2 maiores e 2 menores, $2.2-2.7 \times 1.5-1.6 \mathrm{~cm}$, elípticas a largo lanceolada, verdes, face superior pilosa e inferior com um aglomerado de tricomas mais longos na base. Flor, séssil, pilosa; botão floral 3-15 $\times 15-20 \mathrm{~mm}$, oblongo, ápice semicircular, piloso apenas no ápice. Cálice subulado, $1.2-6 \times 2.5-6 \mathrm{~mm}, 6$ lacínios, iguais, verde, piloso. Corola infundibuliforme, branca ou lilás, prefloração valvar, tubo $8-11 \times 2-4 \mathrm{~mm}$, ereto, cilíndrico, piloso externamente e internamente ao longo de sua extensão, 6 lobos, $2-6 \times 1.5-4 \mathrm{~mm}$, ápice agudo, piloso externamente e internamente. Estames 6, exsertos; filetes 1-1.5 mm comp., glabros; anteras 1-1.2 mm, oblongas, brancas, glabras. Hipanto menor que $1 \mathrm{~mm}$, oblongo, glabro. Ovário trilocular, uniovular, placentação axial; estilete 1-1.5 mm comp., cilíndrico, glabro; estigma trífido, papiloso. Fruto seco, esquizocarpo, 2.5-5 × 4-8 mm, globoso, 3 mericarpos, indeiscentes, verde quando imaturo, marrom quando maduro, papiloso. Semente oblonga, 1.4-3.5 × 1-1.5 mm, sulco longitudinal na face ventral com estrofíolos, face dorsal lisa, marrom.

Material examinado: BRASIL: Paraíba: Cajazeiras, Sítio Serragem, Serra da Arara, 19/VII/2015, fl., fr., A.A. Quaresma 30 (JPB). Santa Helena, Várzea da Ema, Serra da Arrara, 20/III/2016, fl., fr., A.A. Quaresma 45(JPB). 14/V/2016, fl., fr., A. A. Quaresma 58.

Distribuição geográfica: Richardia grandiflora ocorre na região Neotropical, abrangendo Argentina, Bolívia, Paraguai, Uruguai e Brasil (Andersson \& Rova 1999; Mól 2010). Neste último está representada em todas as regiões geográficas e nas áreas com cobertura vegetal dos domínios da Caatinga, Cerrado, Pampa e Mata Atlântica (Flora do Brasil 2020 - em construção). Na Paraíba apresenta-se distribuída do litoral ao Cariri (Pereira \& Barbosa 2006; Pessoa \& Barbosa 2012; Lima \& Barbosa 2014). No Sertão Paraibano foi coletada em áreas abertas, antrópicas e bordas de mata na Serra do Bongá, Monte Horebe, em campos abertos com solos areno-argilosos, margens de estradas e bordas de matas (Pereira \& Pereira 2018).

Considerações: No local de estudo tem ocorrência em ambientes úmidos, regiões alagadas temporariamente e locais com interferência antrópica. Coletada em maio e julho com flores e frutos. Fruto com três mericarpos, ápice do botão floral semicircular, flores hexâmeras e ovário trilocular a diferenciam das demais espécies da Serra. Um dos visitantes florais comuns são as abelhas (Silva et al. 2012). É popularmente conhecida como asa-de-pato na Serra da Arara. 

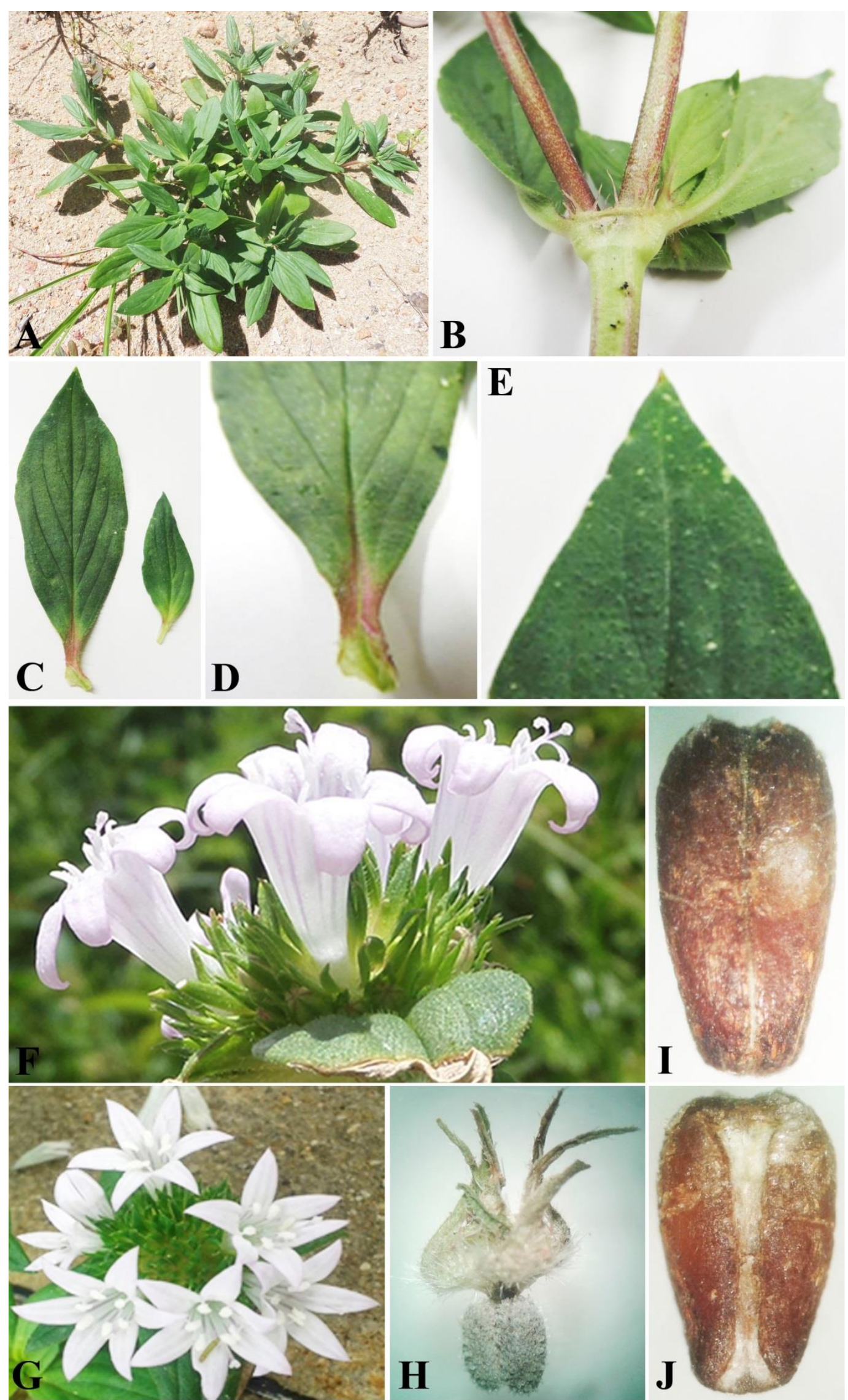

Figura 11. Richardia grandiflora (Cham. \& Schltdl.) Steud.: A. Erva prostrada; B. Estípula interpeciolar; C. Variação do limbo-ovada a elíptica; D. Base atenuada; E. Ápice agudo; F. Inflorescência glomérulo capituliforme; G. Lobos da corola com ápice agudo e estames alternos; H. Esquizocarpo, papiloso; I. Semente lisa (face dorsal); J. Sulco ventral longitudinal com estrofíolos (face ventral). 


\section{Figura 12A-J}

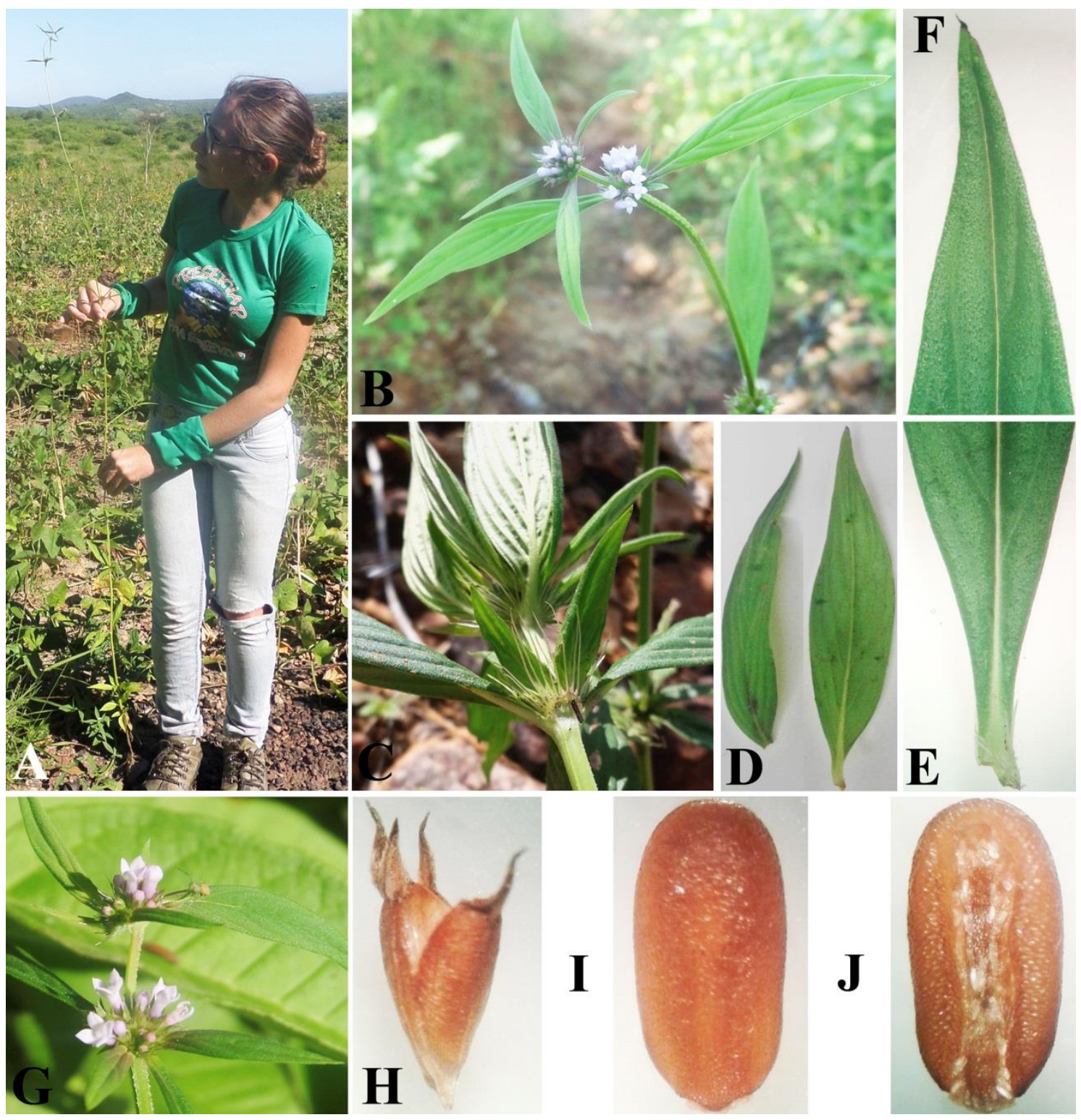

Figura 12. Spermacoce tenuior L.: A. Erva sublenhosa-atingindo $1.70 \mathrm{~m}$; B. Detalhe da inflorescência e folhas opostas, cruzadas; C. Estípula fimbriada; D. Variação do limbo-elíptica a lanceolada; E. Base atenuada; F. Ápice acuminado; G. Inflorescência em glomérulos terminal e axilar; H. Cápsula septícida; I. Semente oblonga (face dorsal); J. Semente com estrofíolos ao longo do sulco longitudinal (face ventral).

Caracterização: Erva ereta a sublenhosa, 0.15-1.70 m alt. Caule tetrangular, verde, não lenticelados, glabro, denticulado ao longo dos ângulos, entrenós $1.8-5 \mathrm{~cm}$. Bainha estipular 4-7 $\times$ 3-4 mm, fimbriada, 7-10 fimbrias, persistentes, pilosa externamente, sem coléteres. Folha oposta cruzada, séssil a peciolada, lâmina 4.1-7.1 $\times 1.2-2.2 \mathrm{~cm}$, elíptica a lanceolada, base acunheada a atenuada, ápice agudo a acuminado, margem inteira, ciliada membranácea, pilosa nas faces superior e inferior, venação eucamptódroma, nervura principal proeminente na face inferior, 4-7 pares de nervuras secundárias, verde; pecíolo 1.8-4.3 × 1.4-1.7 mm. Glomérulo, 4-8 × 3-4 mm, terminal e axilar, séssil, 5-12 flores, 4 brácteas foliáceas, $0.3-2.5 \times 0.2-0.4 \mathrm{~cm}$, lanceoladas, verdes, pilosas nas faces superior e inferior. Flor séssil, glabra; botão floral 1.2-1.5 × 0.5-0.8 mm, oblongo, ápice agudo, piloso. Cálice subulado, 1-1.5 x 0.8-1 mm, 4 lacínios, desiguais, verde, piloso externamente. Corola infundibuliforme, branca ou lilás, prefloração valvar, tubo $1.5-2 \times 0.8-1 \mathrm{~mm}$, ereto, cilíndrico, glabro externamente e piloso internamente, 4 
lobos, 1-1.5 mm comp., ápice triangular, glabro externamente e tomentoso internamente. Estames 4, inclusos, presos a fauce; filetes 1-1.2 mm comp., glabros; anteras $1 \mathrm{~mm}$ comp., oblongas, azuladas, muricadas. Hipanto 1-1.5 mm compr., oblongo, glabro. Ovário bilocular, uniovular, placentação axial; estilete 1-1.3 mm comp., cilíndrico, glabro; estigma bilobado, muricado. Fruto seco, cápsula septicida, $2-3 \times 1.5-1.7 \mathrm{~mm}$, obovoide a linear, cálice persistente, com 2 linhas de deiscência, um mericarpo deiscente, do ápice até a região mediana, e outro indeiscente, verde quando imaturo, marrom quando maduro, piloso externamente. Semente oblonga, $1.5^{-2} \times 0.5-1 \mathrm{~mm}$, sulco ventral com estrofíolos, face dorsal côncava, faveolada, marrom.

Material examinado: BRASIL: Paraíba: São João do Rio do Peixe, Sítio Pé de Serra, Serra da Arara, 07/II/2015, M.S. Pereira, A.A. Quaresma 09. 24/III/2016, fl., fr., A.A. Quaresma 21 (JPB). Santa Helena, Várzea da Ema, Serra da Arara, 03/VI/2016, A.A. Quaresma; A.S. Santos 64 (JPB).

Distribuição geográfica: Spermacoce tenuior ocorre em toda a América Tropical e Subtropical. No Estado da Paraíba, há registros até o momento deste táxon apenas para mesorregião do Cariri em áreas ciliares dos municípios de Camalaú, Caturité e Monteiro (Pessoa \& Barbosa 2012).

Considerações: Na Serra da Arara apresenta-se distribuída nas bordas da mata fechada e úmida, assim como, em plantações agrícolas, florida e frutificada de março a junho, indicando que a mesma se desenvolve no período chuvoso. É facilmente diferenciada de Staelia virgata (Link ex Roem. \& Schult.) K. Schum. por alcançar $1.70 \mathrm{~m}$ de altura, flor lilás após a polinização, estames inclusos e fruto seco constituído por um dos mericarpos deiscente até a região mediana e o outro indeiscente.

8. Staelia virgata (Link ex Roem. \& Schult.) K. Schum., Fl. Bras. 6(6): 76. 1889.

Figura 13A-M

Caracterização: Erva ereta, 7-65 cm alt. Caule cilíndrico a tetrangular, verde a vináceo, não lenticelados, piloso, entrenós 0.9-3.4 cm. Bainha estipular 0.7-0.15 × 0.12-0.4 cm, fimbriada, 3-7 fímbrias, persistentes, pilosa externamente, com coléteres no ápice das fímbrias. Folha oposta dística, pseudoverticilada, lâmina $1.5-3 \times 0.1-0.3 \mathrm{~cm}$, linear a estreitamente elíptica, base atenuada, ápice agudo, margem revoluta, membranácea, pilosa na base da face superior e na nervura principal da face inferior, venação eucamptódroma, nervura principal proeminente na face inferior, 2-3 pares de nervura secundária, verde. Glomérulo, 0.6-1.4 $\times 0.8-2 \mathrm{~cm}$, axilar, raro terminal, séssil, 7-40 flores, 2-3 brácteas foliares, $0.6-2.7 \times 0.1-0.2 \mathrm{~cm}$, linear a estreito elíptica, verde, glabro na face superior com um tufo de tricomas na base e pilosa na nervura principal da face inferior. Flor séssil, pilosa; botão floral 4-6 × 2-2.5 mm, obovado, ápice obtuso, piloso. Cálice subulado, 1.2-2 $20.8-1 \mathrm{~mm}, 2$ lacínios desiguais, verde, piloso. Corola infundibuliforme, branca, prefloração valvar, tubo $2-3 \times 3-5 \mathrm{~mm}$, ereto, afunilado, piloso externamente e com um anel de tricomas internamente na base do tubo; 4 lobos, 1.8-2 $\times 2.1-2.3 \mathrm{~mm}$, ápice agudo, piloso externamente e glabro internamente. Estames 4, exsertos; filetes 1.2-1.8 mm com., glabro; antera $1 \mathrm{~mm}$ comp., oblongas, azuladas, glabras. Hipanto 1-1.2 mm comp., obovado, glabro. Ovário bilocular, uniovular, placentação axial; estilete 6-8 $\mathrm{mm}$ comp., cilíndrico, piloso; estigma bífido, muricado. Fruto seco, cápsula septicida, 1.5-2.8 $\times 0.8-1.2 \mathrm{~mm}$, obovado a oblongo, deiscência transverso oblíquo, cálice persistente, verde quando imaturo e marrom quando maduro, piloso no ápice. Semente obovada, $1-1.2 \times 0.6-0.8 \mathrm{~mm}$, exotesta foveolada a papilosa, dois sulcos longitudinais na face ventral com estrofíolos, face dorsal muricada, castanhoenegrecida.

Material examinado: BRASIL: Paraíba: Santa Helena, Serra da Arara, Várzea da Ema, 14/V/2016, fl., fr., A.A. Quaresma 59 (JPB). 27/V/2016, fl., fr., A.A. Quaresma; A.S. Santos 60. 


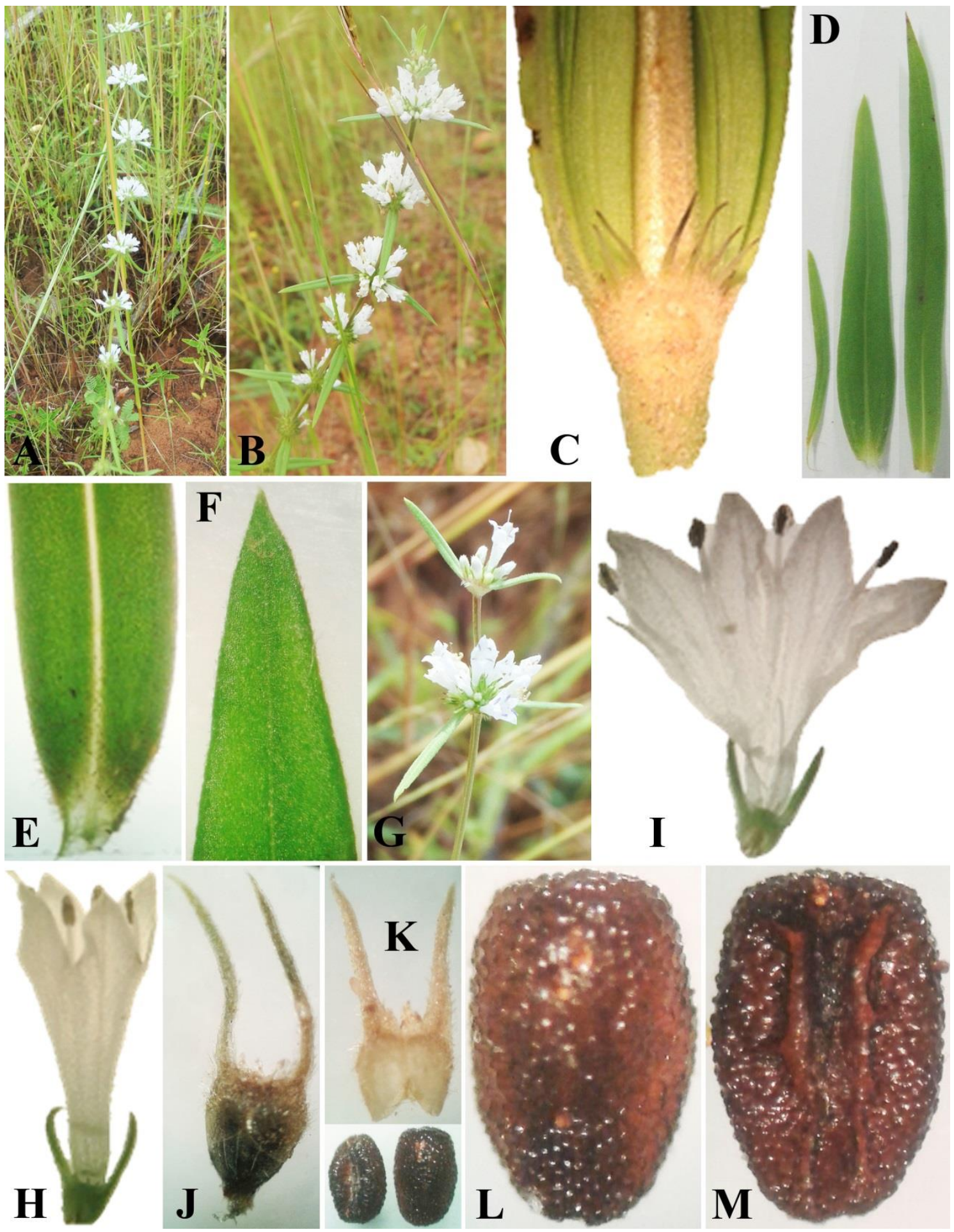

Figura 13. Staelia virgata (Link ex Roem. \& Schult.) K. Schum.: A. Ramo florífero; B. Folhas opostas cruzadas; C. Estípula interpeciolar, fimbriada; D. Variação do limbo-linear (L) a estreitamente elíptica (EE); E. Base atenuada; F. Ápice agudo; G. Inflorescência em glomérulo; H. Cálice subulado; I. Estames exsertos; J. Cápsula septícida; K. Deiscência transverso obliquo; L. Semente muricada-face dorsal; M. Dois sulcos longitudinais-face ventral.

Distribuição geográfica: Staelia virgata está presente no norte da Argentina, Brasil, Bolívia, Peru e Paraguai (Souza \& Sales 2004; Pereira \& Barbosa 2006). Ocorre em todas as regiões brasileiras e em ambientes de Caatinga, Amazônia, Cerrado, Mata Atlântica e Pantanal (Pessoa \& Barbosa 2012; Flora do Brasil 2020 - em construção). Na Paraíba está distribuída no Cariri (Fazenda Almas, Cariri), no litoral (Mamanguape) na borda de mata, em solos arenosos, com 
luminosidade intensa e vegetação arbustivo-herbácea (Pereira \& Barbosa 2006; Pessoa \& Barbosa 2012) e no sertão paraibano (Monte Horebe) em campos abertos com solo areno-argiloso e altitude média de $650 \mathrm{~m}$, tal como disposta na Serra do Bongá (Pereira \& Pereira 2018).

Considerações: Apresenta-se fértil, com flor e fruto, nos meses de maio, junho e julho, perpassando o período chuvoso até o início da escassez hídrica. Foi coletada em ambientes secos, de solos argilosos, frequente no entorno da Serra em associação com espécies da família Poaceae (Gramineae). Folhas pseudoverticiladas, margem revoluta, estigma bífido e frutos com deiscência transverso oblíqua a diferencia de Spermacoce tenuior.

\section{Tocoyena formosa (Cham. \& Schltdl.) K. Schum., Fl. bras. 6(6): 347, 1889.}

\section{Figura 14A-K}

Caracterização: Arvoreta ereta, 2-2.5 m alt. Caule cilíndrico, acinzentado, lenticelado nos ramos, glabro, entrenós $0.6-4.6 \mathrm{~cm}$. Estípulas 0.3-0.6 × 0.2-0.4 cm, inteira, caducas, triangulares, ápice agudo, pubescente externamente, com coléteres internamente na base. Folha oposta dística, peciolada, lâmina 9.3-12.4 × 4.7-6.0 cm, elíptica a oblongo-lanceolada, base acunheada, ápice agudo a mucronado, margem inteira, coriácea a cartácea, verde, tomentosa nas faces superior e inferior, venação camptrodoma, nervura principal proeminente na face inferior, 8-10 pares de nervuras secundárias, verde, pecíolo 1.4-1.7 × 0.4-0.45 cm, verde, piloso. Dicásio, 10-15 × 3.5-4.5 $\mathrm{cm}$, terminal, pedunculado ou séssil, $2-4$ flores, brácteas ausentes, 1 bractéola foliácea, $7-12 \times$ $5.4-6.5 \mathrm{~cm}$, elíptica a lanceolada, verde, pilosa; pedúnculo $0.4-0.5 \times 0.3-0.28 \mathrm{~cm}$, lenticelados, verde, tomentoso. Flor séssil, pilosa externamente e internamente; botão floral 7.6-10 × 0.3-0.4 $\mathrm{cm}$, oblongo, ápice agudo, piloso. Cálice campanulado, 0.7-0.8 $\times 0.4-0.5 \mathrm{~cm}$, 5-denticulado, verde, tomentoso. Corola hipocrateriforme, amarela, prefloração contorta, tubo $8-9.5 \times 2.5-3 \mathrm{~cm}$, ereto, cilíndrico, tomentoso externamente e glabro internamente, 5 lobos, $1.5-2.0 \times 1-1.2 \mathrm{~cm}$, oblongos a obovados, ápiceagudo, tomentoso externamente e internamente com um anel de tricomas próximo a fauce. Estames 5, exsertos, presos a fauce; filetes 1-1.5 mm compr., glabros; antera 3-7 mm compr., oblonga, amarela, glabra. Hipanto 4-8 × 1.1-1.3 mm, oblongo, glabro. Ovário bilocular, pluriovular, placentação axial; estilete 9.2-10.3 cm compr., cilíndrico, glabro; estigma bífido, piloso. Baga, $2.5 \times 3.6 \mathrm{~cm}$ comp., globoso, cálice persistente, verde quando imaturo, enegrecido quando maduro, híspido. Sementes discoides, $0.3-0.7 \times 0.3-0.5 \mathrm{~cm}$, sulcos ausentes, amarelas, lisas.

Material examinado: BRASIL: Paraíba: Santa Helena, Várzea da Ema, Serra da Arara, 06/III/2016, fl., fr., A.A. Quaresma; A.S. Santos 42 (JPB). 28/02/2016, fl., fr., A.A. Quaresma; A.S. Santos 39.

Distribuição geográfica: Tocoyena formosa distribui-se no Neotrópico, com registros para o Paraguai, Bolívia e Brasil, nas regiões Norte, Nordeste, Centro-oeste, Sul e Sudeste, abrangendo os domínios fitogeográficos da Caatinga, Amazônia, Cerrado e Mata Atlântica (Jung-Mendaçolli 2007; Flora do Brasil 2020 - em construção). Na Paraíba foi encontrada nas mesorregiões do litoral, Cariri e Sertão, nos municípios de Cabaceiras, São José dos Cordeiros, Serra Branca, Mamanguape, Cabedelo, Santa Rita e João Pessoa (Pereira \& Barbosa 2004; Pessoa \& Barbosa 2012; Lima \& Barbosa 2014), em ambientes serranos (Serra do Bongá), campos abertos, vegetação densa e ainda em áreas antropizadas (Pereira \& Pereira 2018).

Considerações: Foi encontrada ao longo da Serra, assim como, em áreas de influência antrópica, florida e frutificada de fevereiro a junho, evidenciando que o período fértil incide nos meses do período chuvoso. Folhas tomentosas em ambas as faces, tubo da corola tomentoso, botão floral piloso, cálice com cinco dentículos e fruto híspido, a diferencia de Tocoyena sellowiana (Cham. \& Schltdl.) K. Schum. É popularmente conhecida como "jenipapo bravo" sendo amplamente utilizada na alimentação e cicatrização de ferimentos (Coelho et al. 2006). 


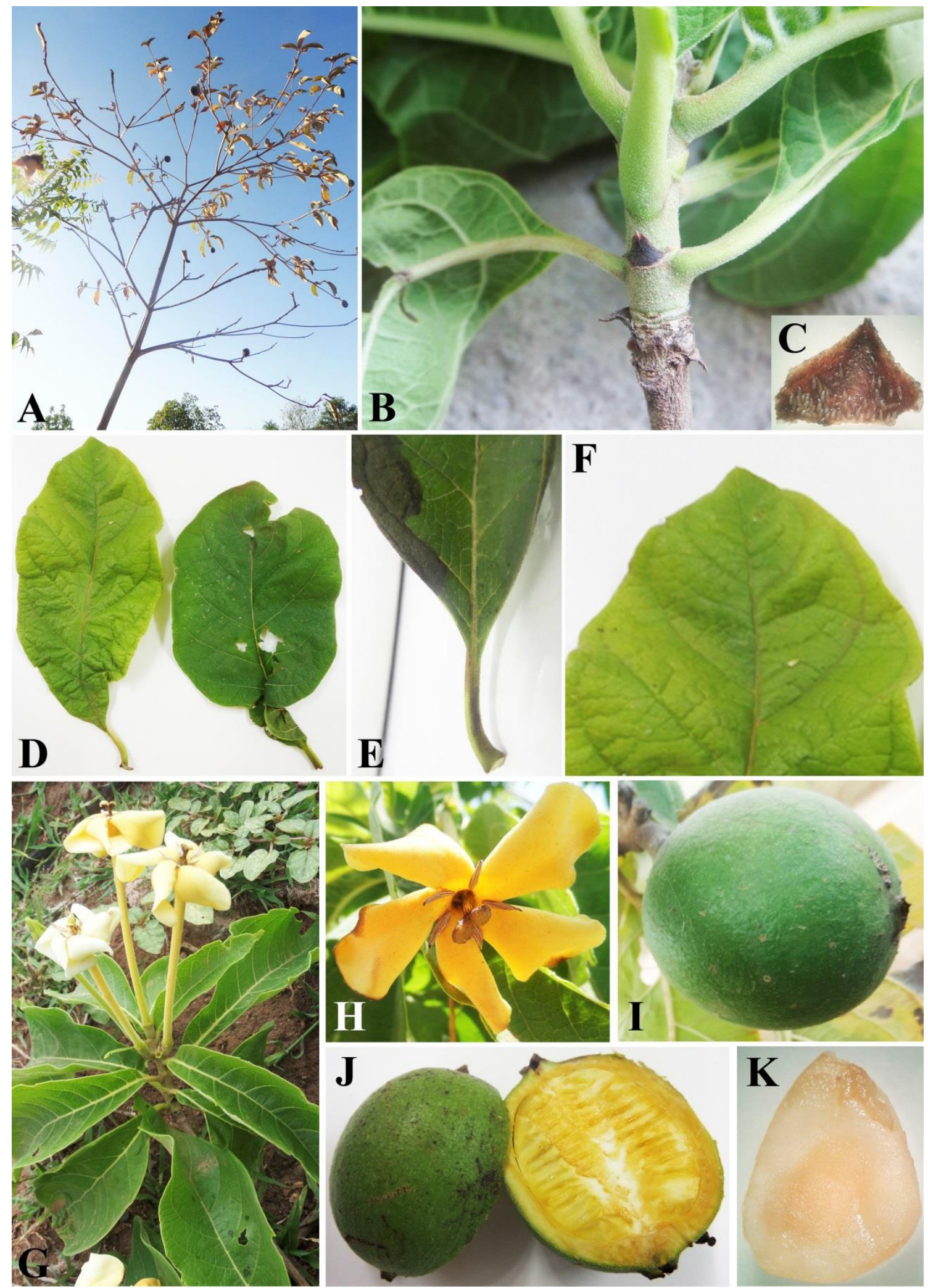

Figura 14. Tocoyena formosa (Cham. \& Schltdl.) K. Schum.: A. Arvoreta ereta; B. Estípula interpeciolar, inteira; C. Coléteres na região interna da estípula; D. Variação do limbo-elíptica a oblongo-lanceolada; E. Base acunheada; F. Ápice agudo; G. Corola hipocrateriforme; H. Lobos obovados; I. Baga; J. Distribuição de sementes-corte longitudinal; K. Semente discoide. 
10. Tocoyena sellowiana (Cham. \& Schltdl.) K. Schum., Fl. bras. 6(6): 349. 1889.

Figura 15A-J
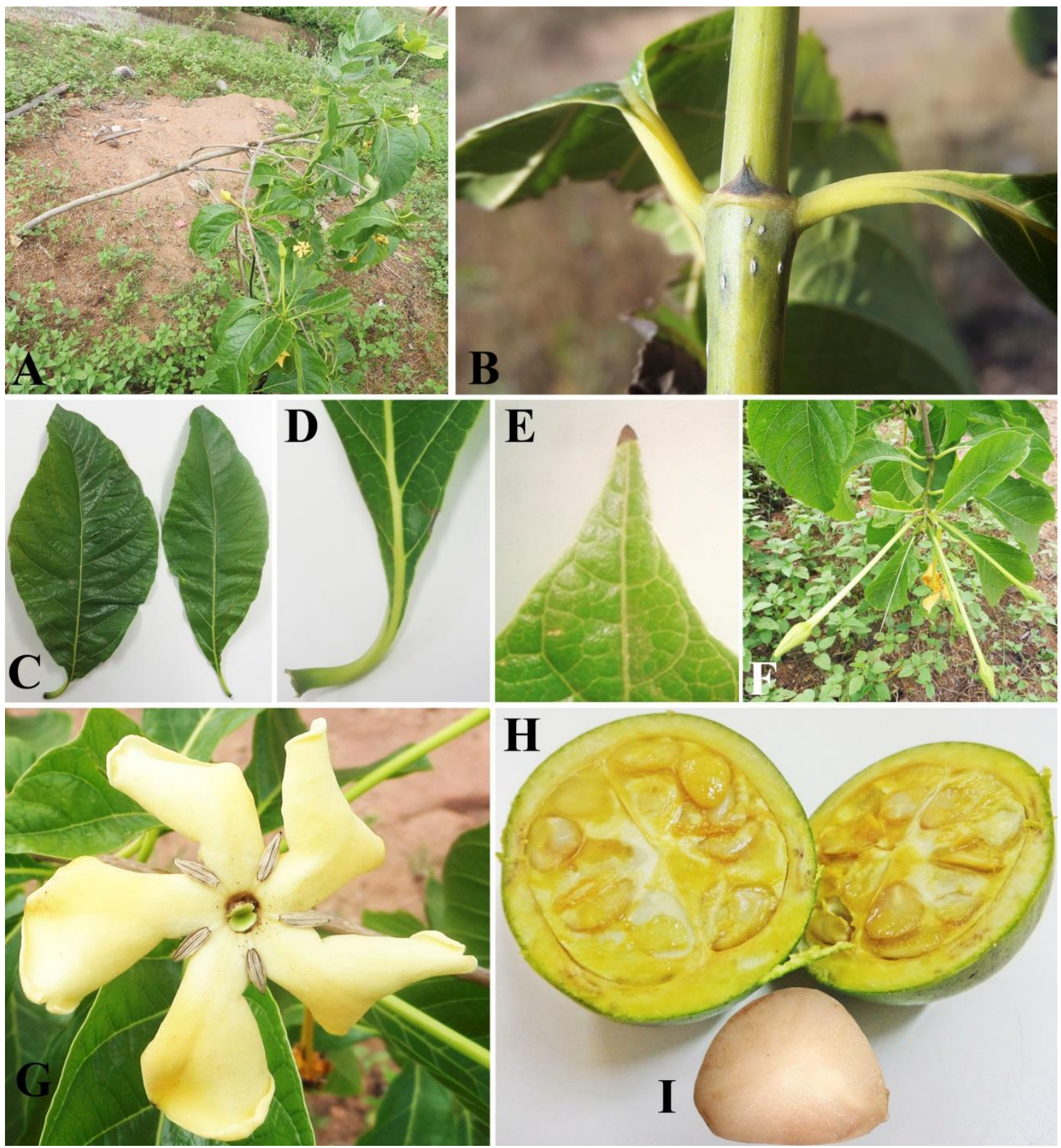

Figura 15. Tocoyena sellowiana (Cham. \& Schltdl.) K. Schum.: A. Arvoreta ereta; B. Estípula interpeciolar, inteira; C. Variação do limbo-elíptica a obovada; D. Base atenuada; E. Ápice acuminado; F. Dicásio; G. Lobos obovados; H. Baga; I. Distribuição das sementes-corte transversal; J. Semente discoide.

Caracterização: Arvoreta ereta, 2-4 m alt. Caule cilíndrico, acinzentados, lenticelados próximo aos ramos, glabro, entrenós $1.0-1.2 \times 1.8-2.0 \mathrm{~cm}$. Estípula $0.4-0.6 \times 0.3-0.4 \mathrm{~cm}$, inteira, caducas, triangulares, ápice agudo, externamente glabra, com coléteres internamente. Folha oposta cruzada, peciolada; lâmina 14.4-15.5 × 5.3-7.9 cm, elíptica, largamente lanceolada a obovada, base atenuada a acunheada, ápice acuminado a cuspidado, margem inteira a revoluta, coriácea a cartácea, glabra, lustrosa nas faces superior e inferior, venação camptódroma, nervura principal e secundarias proeminentes na face inferior, 7-12 pares de nervura secundária, verde; pecíolo 0.9-2.7 cm, verde, glabro. Dicásio, 10-12 cm, terminal, pedunculado ou séssil, 3-5 flores, 2 brácteas foliáceas, 7-12 × 5.4-6.5 cm, elípticas, verdes, glabras; pedúnculo $3-5 \times 2.5-3 \mathrm{~mm}$, lenticelado, verde. Flor séssil, glabra; botão floral 9-11 × 2-3 cm, oblongo, ápice agudo, glabro. Cálice campanulado, 10-12 × 5-6 mm, 6-denticulado, iguais, verde, glabro. Corola 
hipocrateriforme, amarela, prefloração contorta, tubo 9.5-10 × 3-3.5 cm, ereto, cilíndrico, glabro externamente e internamente com um anel de tricomas, 10-15 mm, 5 lobos, 2.0-2.5 × 1.3-1.4 $\mathrm{cm}$, oblongos a obovado, ápice agudo, glabro externamente e tomentoso internamente. Estames 5 , exsertos, presos a fauce; filetes 1-2 $\mathrm{mm}$ comp., glabros; anteras 5-8 $\mathrm{mm}$, oblongas, amarelas, glabras. Hipanto 5-8 mm comp., oblongo, glabro. Ovário bilocular, pluriovular, placentação axial; estilete 9.5-10.4 cm comp., cilíndrico, glabro; estigma bífido, piloso. Fruto carnoso, baga, $4.2 \times 3.8 \mathrm{~cm}$, globoso, cálice persistente, verde quando imaturo, enegrecido quando maduro, glabro. Semente discoide, $0.6-0.8 \times 0.4-0.5 \mathrm{~cm}$, lisas a levemente muricada, branca.

Material examinado: BRASIL: Paraíba: Santa Helena, Serra da Arara, Várzea da Ema, 28/II/2016, fl., fr., A.A. Quaresma; A.S. Santos 40 (JPB).

Distribuição geográfica: Tocoyena sellowiana distribui-se do Brasil as Guianas (Guiana, Guiana Francesa e Suriname) (Andersson 1992; Mól 2010). No Brasil ocorre nas regiões Norte, Nordeste, Sul e Sudeste e em áreas de Caatinga, Amazônia e Cerrado. Na Paraíba a espécie é tratada no trabalho de Pereira \& Barbosa (2004); Pessoa \& Barbosa (2012) evidenciando sua ocorrência no litoral (Mamanguape e Rebio Guaribas), Cariri (Monteiro) e Sertão Paraibano (na Unidade de Conservação do Monumento Natural Vale dos Dinossauros) no município de Sousa (Gadelha Neto \& Barbosa 2007).

Considerações: Espécimes com flores e frutos foram coletados na Serra da Arara durante os meses de fevereiro a julho, que compreendem a estação chuvosa mostrando a importância de recurso hídrico para o período fértil da espécie seja estabelecido. As características diagnósticas que a diferença de Tocoyena formosa são as folhas glabras, lustrosas, flor com papilas, fruto glabro e cálice com 6 dentículos. Na região, o nome vernacular é idêntico ao utilizado para Tocoyena formosa, "jenipapo brabo", esta, segundo população nativa (moradores), é utilizada na alimentação e também como fitoterápico.

\section{Considerações finais}

A Serra da Arara constitui uma área com significativa riqueza biológica, ficando evidenciado neste trabalho, o qual se trata do primeiro estudo abordando dados com informações florísticas.

Apesar da vasta heterogeneidade biológica, o ambiente vem sofrendo intensas ações antrópicas que ameaçam as formas de vida presentes nesta localidade. Assim, é evidente a importância do conhecimento da biodiversidade na região para que demais estudos sejam desenvolvidos visando a implementação de programas e projetos que favoreçam a manutenção dessa biota.

\section{Agradecimentos}

As autoras agradecem aos revisores pelas contribuições; as equipes técnicas do Herbário Lauro Pires Xavier (JPB) e do Laboratório de Botânica do CFP/UFCG pelo apoio ao longo do desenvolvimento deste trabalho e a CAPES pela concessão das bolsas de estudo que fomentaram a realização do mesmo.

\section{Referências}

Andersson L. (1992) A provinsional Checklist of Neotropical Rubiaceae. Scripta Botanica Belgica, 1(1): 1-199.

Andersson, L. \& Rova, J.H.E. (1999) The rps16 intron and the phylogeny of the Rubioideae (Rubiaceae). Plant Systematics and Evolution, 214: 161-186.

https://doi.org/10.1007/BF00985737 
Bremer B. (1996) Combined and separate analyses of morphological and molecular data in the plant Family Rubiaceae. Cladistics, 12(1): 21-40. https://doi.org/10.1006/clad.1996.0003

Bremer B. \& Eriksson T. (2009) Time tree of Rubiaceae: phylogeny and dating the Family, subfamilies and tribes. International Journal of Plant Sciences, 170(6): 766-793. https://doi.org/10.1086/599077

Cabral E.L. \& Bacigalupo N.M. (1999) Estudio de las Especies Americanas de Borreria Series Laeves (Rubiaceae, Spermacoceae). Darwiniana, 37(3-4): 259-277.

Cabral E.L., Miguel L.M. \& Salas R.M. (2011) Duos especies nuevas de Borreria (Rubiaceae), sinopsis y clave de las especies para Bahia, Brasil. Acta Botanica Brasilica, 25(2): 255-276. http://dx.doi.org/10.1590/S0102-33062011000200002

Coelho V.P.M., Agra M.F. \& Barbosa M.R.V. (2006) Estudo farmacobotânico das folhas de Tocoyena formosa (Cham. \& Schltdl.) K.Schum. (Rubiaceae). Revista Brasileira de Farmacognosia, 16(2): 170-177. http://dx.doi.org/10.1590/S0102-695X2006000200007

Cronquist A. (1981) An integrated system of classification. New York: Columbia Universitu Press. $1262 \mathrm{p}$.

Delprete P.G. \& Cortes-B R. (2006) Synopsis of the Rubiaceae of the states of Mato Grosso and Mato Grosso do Sul, Brazil, with a key to genera, and a preliminary species list. Revista Biologia Neotropical, 3(1): 13-96. http://dx.doi.org/10.5216/rbn.v3i1.2813

Delprete P.G. \& Jardim J.G. (2012) Systematics, taxonomy and floristics of Brazilian Rubiaceae: an overview about the current status and future challenges. Rodriguésia, 63(1): 101-128. http://dx.doi.org/10.1590/S2175-78602012000100009

Flora do Brasil (2020) - em construção. Jardim Botânico do Rio de Janeiro. Disponível em: http://floradobrasil.jbrj.gov.br (acesso em: 28/07/2019).

Gadelha Neto P.C. \& Barbosa M.R.V. (2007) Composição florística do Monumento Natural Vale dos Dinossauros, Sousa, Paraíba, Brasil (p. 1-19). In: Loiola, M.I.B; Silva, M.A.P.; Barros, L.M. (Orgs). XXX Reunião Nordestina de Botânica. Anais. Crato: Universidade Regional do Cariri.

Gadelha Neto P.C., Lima J.R., Barbosa M.R.V., Barbosa M.A., Menezes M., Pôrto K.C., Wartchow F. \& Gilbertoni T.B. (2013) Manual de Procedimentos para Herbários. Recife: Ed. Universitária da UFPE. 53 p.

Gardner G. (1838) XVII. - An account of a Journey to, and a Residence of nearly Six Months in, the Organ Mountains, with Remarks on their Vegetation. Annals of Natural History, 1: 165181.

IBGE (2017) Divisão Regional do Brasil. Disponível em: https://ww2.ibge.gov.br/home/geocienci as/geografia/default_div_int.shtm?c=1 (Acesso em: 11/08/2019).

Lima I.B. \& Barbosa M.R.V. (2014) Composição Florística da RPPN Fazenda Almas, no Cariri Paraibano, Paraíba, Brasil. Revista Nordestina de Biologia, 23(1): 49-67.

Melo A.S. \& Barbosa M.R.V. (2007) O gênero Borreria G.Mey (Rubiaceae) na Mata do Buraquinho, João Pessoa, Paraíba. Revista Brasileira de Biociências, 5(2): 627-629.

Mendonça A.C.A.M., Silva M.A.P., Seixas E.N.C. \& Santos M.A.F. (2013) Rubiaceae: aspectos ecológicos e reprodutivos. Caderno de Cultura e Ciência, 12(2): 1-13. http://dx.doi.org/10.14295/cad.cult.cienc.v12i2.630

Jung-Mendaçolli S.L. (2007) Rubiaceae (p. 259-446). In: Wanderley M.G.L., Shepherd G.J., Melhem T.S. \& Giulietti A.M. (Orgs). Flora Fanerogâmica do Estado de São Paulo. Volume 5. São Paulo: Instituto de Botânica. 523 p.

Martius C.V.P. (1888) (Ed.). Flora Brasiliensis, 6(6): 1-123 p.

Martius C.V.P. (1889) (Ed.). Flora Brasiliensis, 6(6): 124-466.

Mendonza H., Ramirez B.R. \& Jimenéz L.C. (2004) Rubiaceae de Colombia: Guía ilustrada de géneros. Bogota: Instituto de Investigación de Recursos Biológicos Alexander von Humboldt. $351 \mathrm{p}$.

Menezes H.E.A., Brito J.I.B., Santos A.C. \& Silva L.L. (2008) A relação entre a temperatura da superfície dos oceanos tropicais e a duração dos veranicos no estado da Paraíba. Revista Brasileira de Meteorologia, 23(2): 152-161. http://dx.doi.org/10.1590/S0102-77862008000200004 
Mól D.F.F. (2010) Rubiaceae em um Remanescente de Floresta Atlântica no Rio Grande do Norte, Brasil. Dissertação de Mestrado, Programa de Pós-Graduação em Ciências Biológicas. Universidade Federal do Rio Grande do Norte, Natal, Rio Grande do Norte.

Müller Argovensis J. (1875) Rubiaceae brasilienses novae. Flora, 58(30): 465-480.

Müller Argovensis J. (1881) Rubiaceae (p. 1-470). In: Martius C.F.P. (Ed.). Flora Brasiliensis, 6(5): $1-470$.

Nepomuceno F.Á.A., Souza E.B., Nepomuceno I.V., Miguel L.M., Cabral E.L. \& Loiola M.I.B. (2018) O gênero Borreria (Spermacoceae, Rubiaceae) no estado do Ceará, Brasil. Rodriguésia 69(2): 715-731. http://dx.doi.org/10.1590/2175-7860201869232

Pereira A.S. \& Pereira M.S. (2018) Diversidade de Rubiaceae Juss. na Serra do Bongá, Alto Sertão Paraibano (p. 55-76). In: Oliveira, A.C. (Eds). Botânica aplicada. Ponta Grossa: Atena. 202 p.

Pereira M.S. \& Barbosa M.R.V. (2004) A família Rubiaceae na Reserva Biológica Guaribas, Paraíba, Brasil. Subfamílias Antirheoideae, Cinchonoideae e Ixoroideae. Acta Botanica Brasilica, 18(2): 305-318. http://dx.doi.org/10.1590/S0102-33062004000200010

Pereira M.S. \& Barbosa M.R.V. (2006) A família Rubiaceae na Reserva Biológica Guaribas, Paraíba, Brasil. Subfamília Rubioideae. Acta Botanica Brasilica, 20(2): 455-470. http://dx.doi.org/10.1590/S0102-33062006000200021

Pessoa M.C.R. \& Barbosa M.R.V. (2012) A família Rubiaceae Juss. no Cariri Paraibano. Rodriguésia, 63(4): 1019-1037. http://dx.doi.org/10.1590/S2175-78602012000400017

Robbrecht E. (1988) Tropical woody Rubiaceae. Opera Botanica Belgica, 1: 1-271.

Schumann K. (1888) Rubiaceae (p. 1-123). In: Martius C.V.P. (Ed.). Flora Brasiliensis, 6(6): 1-123.

Schumann K. (1889) Rubiaceae (p. 124-466). In: Martius C.V.P. (Ed.). Flora Brasiliensis, 6(6): 124466.

Silva C.M., Hrncir M., Queiroz R.T. \& Imperatriz-Fonseca V.L. (2012) Guia de plantas: visitadas por abelhas na Caatinga. Fortaleza: Editora Fundação Brasil Cidadão. 99 p.

Souza B.E., Andrade I.M., Melo L.M.B. \& Silva M.F.S. (2014) Rubiaceae do Município de Ilha Grande, Piauí, Brasil. Theringia, 69(1): 155-165.

Souza B.I., Artigas R.C. \& Lima R.V.L. (2015) Caatinga e Desertificação. Mercator, 14(1): 131-150. http://dx.doi.org/10.4215/RM2015.1401.0009

Souza E.B. \& Sales M.F. (2004) O gênero Staelia Cham. \& Schltdl. (Rubiaceae - Spermacoceae) no Estado de Pernambuco, Brasil. Acta Botanica Brasilica, 18(4): 919-926. http://dx.doi.org/10.1590/S0102-33062004000400023

Souza V.C., Flores T.B. \& Lorenzi H. (2013) Introdução à botânica: morfologia. São Paulo: Instituto Plantarum da Flora. $223 \mathrm{p}$.

Stevens P.F. (2019 - onwards) Angiosperm Phylogeny Website. Version 14, July 2017 [and more or less continuously updated since]." Disponível em: http://www.mobot.org/MOBOT/research/ APweb/ (Acesso em: 18/04/2019).

Vidal W.N \& Vidal M.R.R. (2003) Botânica-organografia: quadros sinóticos ilustrados de fanerógamos. $4^{\circ}$ edição. Viçosa: UFV. 124 p.

Vellozo J.M.C. (1827) Rubiaceae (p. 62-68). In: Vellozo J.M.C. Florae Fluminensis. Volume 2. Paris: Pareeses. $156 \mathrm{p}$

Zappi D.C., Barbosa M.R.V., Calió M.F., Jardim J.G., Pereira M.S. \& Souza E.B. (2009) Rubiaceae (p. 449-461). In: Stehmann J.R. (Eds) Plantas da Floresta Atlântica. Rio de Janeiro. 515 p. 